\title{
Upstream Natural Resource Piracy-Caused Universality-Lost Economic Health Index GDP
}

\author{
Miah M Adel \\ Department of Chemistry \& Physics, University of Arkansas at Pine Bluff \\ 1200 North University Drive, USA \\ adelm@uapb.edu
}

Abstract: The elixir of life water is a transboundary resource. It is essential for ecosystem's sustainability, climatic stability, hygienic soundness, agricultural and industrial productions, transportation, and overall economic growth that contribute, directly and indirectly, to GDP. Some upstream riparian countries are confining international water resources in their own territories depriving downstream countries. Downstream countries are forced to use their groundwater reserve that takes hundreds of years to build up. The scarcity of surface water resources along with the groundwater extraction to compensate the unavailability of surface water resources unfolds a host of environmental problems for the downstream countries the removal of which along with the cost of purchasing the water to fill the pirated amount can neither hold the GDP static nor can increase it. Whereas the upstream countries are gaining natural resources, the downstream countries are losing it. The downstream governments show GDP figures which do not represent the countries' holistic resource-based economic condition to be at par with the natural resource-intact and the natural-resource-pirating countries. Thus the upstream water piracy has invalidated the international economic health index GDP.

Keywords: Renewable natural resources, upstream water piracy, barrage, surface water, groundwater, Ganges River, navigability, extreme climate, natural calamities, irrigation, lighting, human nutritional intakes, arsenic disaster, livelihood, species extinction, agricultural practice, recreational activities, river sediment, saline water, intellectual degeneration, GDP, and flooding.

\section{INTRODUCTION}

Natural resources are the principal factor for the economic growth of a country. Natural resources include the land area, the soil quality, water resources, forests, minerals, and fuel resources. If a country lacks natural resources, it has to import them. On the contrary, a naturally resourceful country can export them and be rich. Water is a renewable resource. This elixir of life may be placed next to land for the purpose of productivity and next to the transboundary natural resource air for survivability. Some nations are defining and keeping their water resources within their land boundaries against its mobile nature (Adel, 2013a, 2015a, 2015b, 2015c, 2015d, 2015e, 2016). Upstream countries are at an advantage to pirate this resource from the downstream countries' shares. This is a cornering weapon for the upstream countries against the downstream countries for subjection. The downstream countries' economic condition is not reflected in the GPD figure which never included the loss of natural resource or its depreciation, a fact that is not found when the GDP idea was introduced. If a water-abundant ecosystem is turned water-short, many calamities appear (Miah, 1989, 1996a, 1996b; Adel, 1999a, 1999b, 1999C, 2000a, 2000b, 2001, 2002, 2003, 2004a, 2004b, 2005, 2008a, 2008b, 2008c, 2012a, 2012b, 2013b, 2013c, 2013d, 2013e, 2013f, 2013g, Adel and Husain, 2008, 2014, Adel et al., 2014). This article basically reviews the principal calamities to illustrate the loss of the universality of GDP as this economic index is not truly an index of economic health for the resource-lost country as it is for a resourceful and resource-gaining country. As such GDP index should be dropped for uniformity of comparison and for the transparency of the economic condition of nations.

www.arjonline.org

Page 1 


\section{Internationality of THE Major SuRface WATER Resources}

Water resource is international country-wise as well as continent-wise. Africa, a continent of 116 international rivers and 55 countries, has the largest percentage of areas among the international river basins, and Europe, a continent of 200 international rivers and 50 nations, has the largest number of international river basins.

Worldwide, 39 countries fall within $90-100 \%$ international river basins, 11 with 80-90\%, 14 within 70-80\%, another 11 within $60-70 \%, 17$ within 50-60\%, 10 within 40-50\%, another 10 within 30-40\%, 13 within $20-30 \%$, 9 within $10-20 \%$, and 11 within $0.01-10 \%$.

Specific river-wise, the Danube River in Europe serves the largest number of countries. The next number of riparian countries ranges between 9 and 11 in an international river basin. These international basins are the Congo, the Niger, the Nile, the Rhine, and Zambezi. The third category includes 5-8 riparian countries. These rivers are the Amazon, the Ganga-Brahmaputra-Meghna, the Lake Chad, the Tarim, the Aral Sea, the Jordan, the Kura Arks, the Mekong, the Tigris-Euphrates, the Volga, the La Plata, the Neman and the Vistula (Wolf et al., 1999).

The frequency of just two countries that share a basin is 172 which is the highest. No twelve, fourteen, fifteen, and sixteen share a basin (Product of the Transboundary Freshwater Dispute Database, Department of Geosciences, Oregon State University. Additional information about the TFDD can be found at: http://www. transboundarywaters.orst.edu). So, the internationality of the water resources cannot be ignored.

\section{Examples of Natural Resource Piracy}

\subsection{The Ganges River}

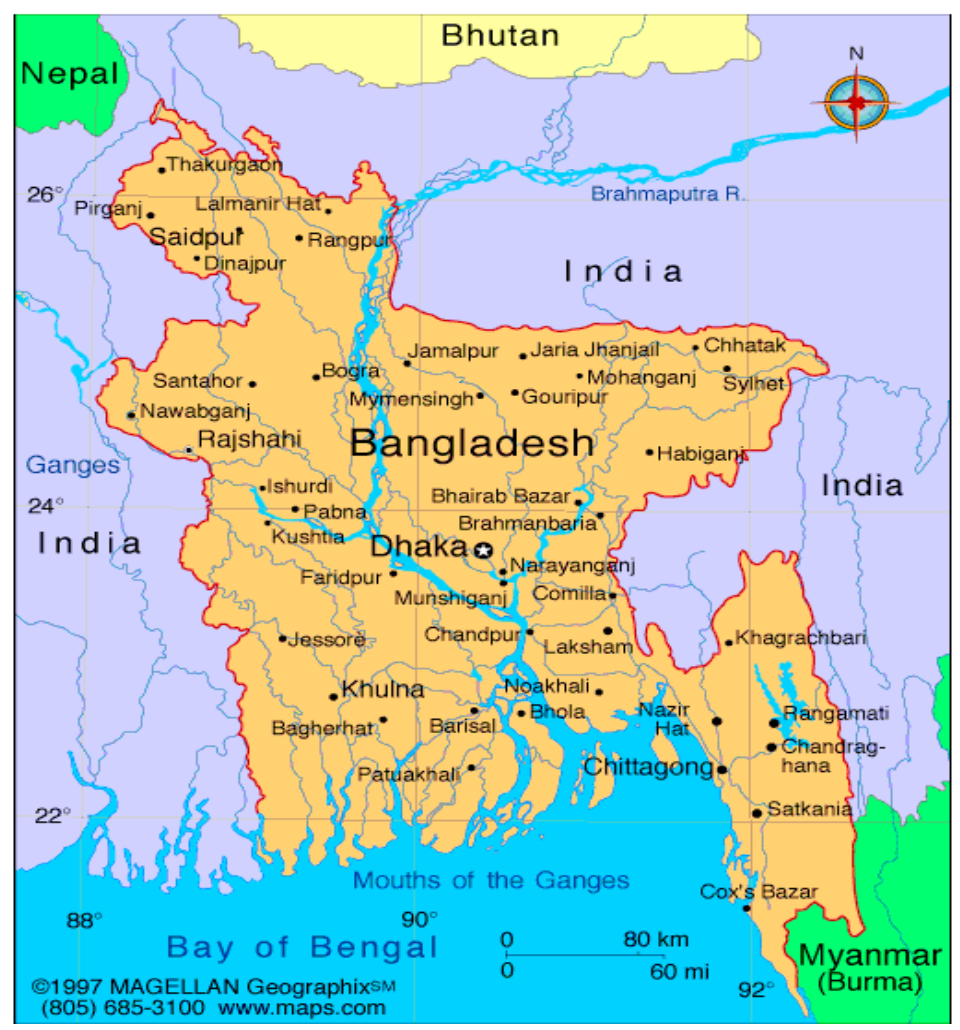

Fig1. Map of Bangladesh (http://www.infoplease.com/atlas/country/bangladesh.html) 
Bangladesh (Fig. 1) and India shares 58 common rivers (Figs. 2 and 3) a few of which is common to China, Nepal, and Bhutan. The principal rivers are the Ganges, the Brahmaputra, and the Meghna.. The percentages of the total areas of India, China, Nepal, and Bangladesh in the Ganges basin are 26, 0.3, 100, and 32, respectively ((http://www.fao.org/nr/water/aquastat/basins/gbm/index.stm). In the Brahmaputra basin, the percentages of areas of India, China, Bangladesh, and Bhutan are 6, 3, 27, and 100, respectively. And in the Meghna basin, ther percentages of areas of India and Bangladesh are 1 and 24, respectively

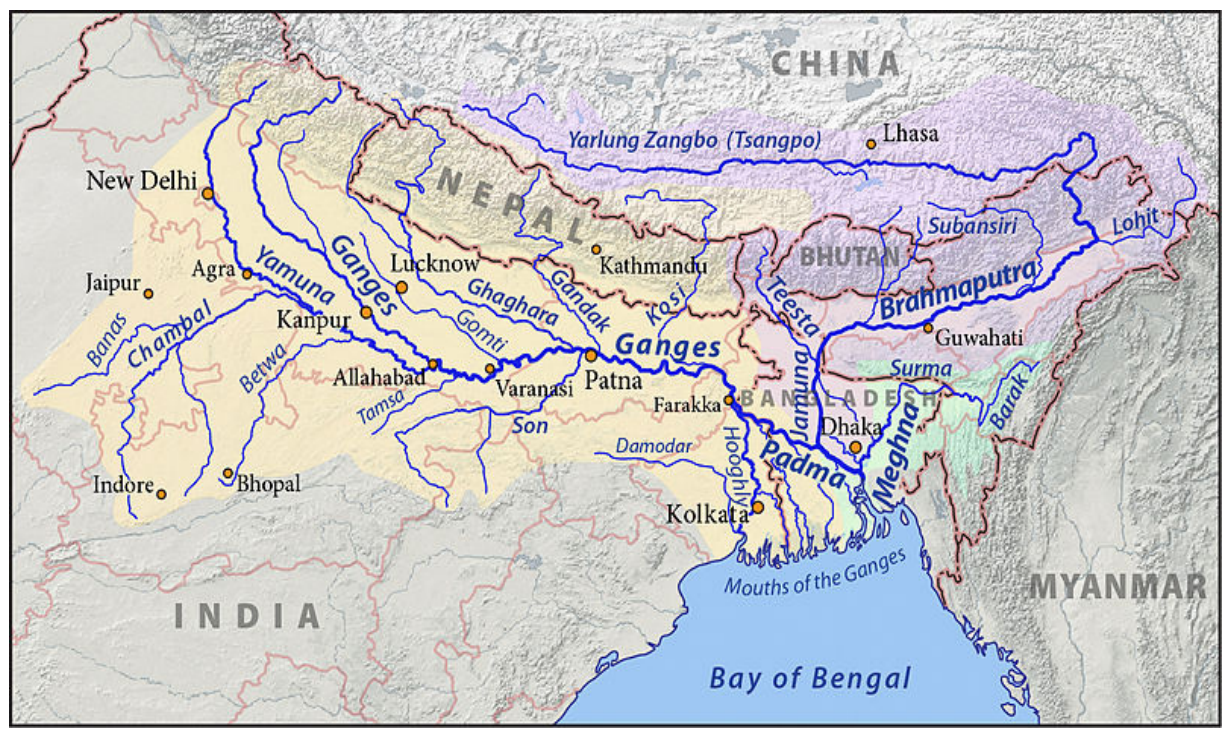

Fig.2. The Brahmaputra, Ganges, and Meghna basins (Pfly, 2011)

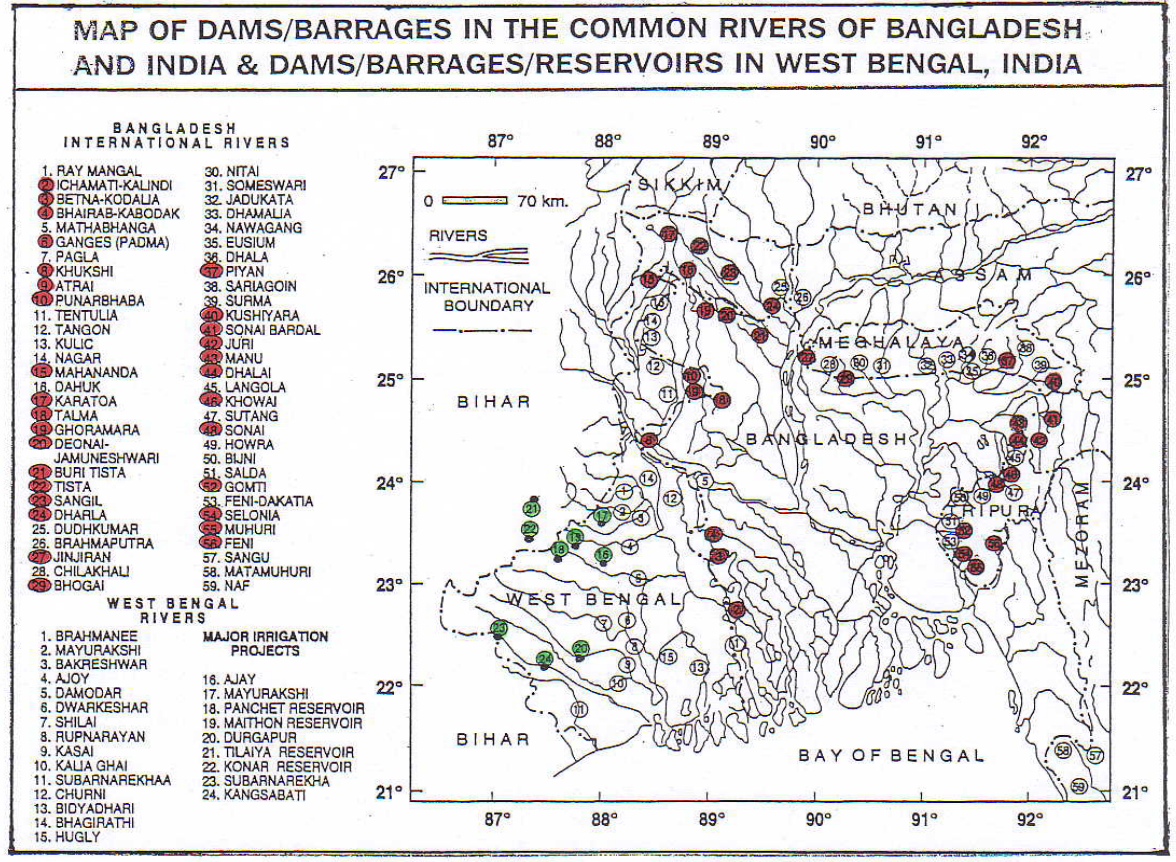

Fig3. The Great Ring of Dams and Barrages around the Bangladesh border, a unique technique of subjugating little neighbors (Adel, 2001). 

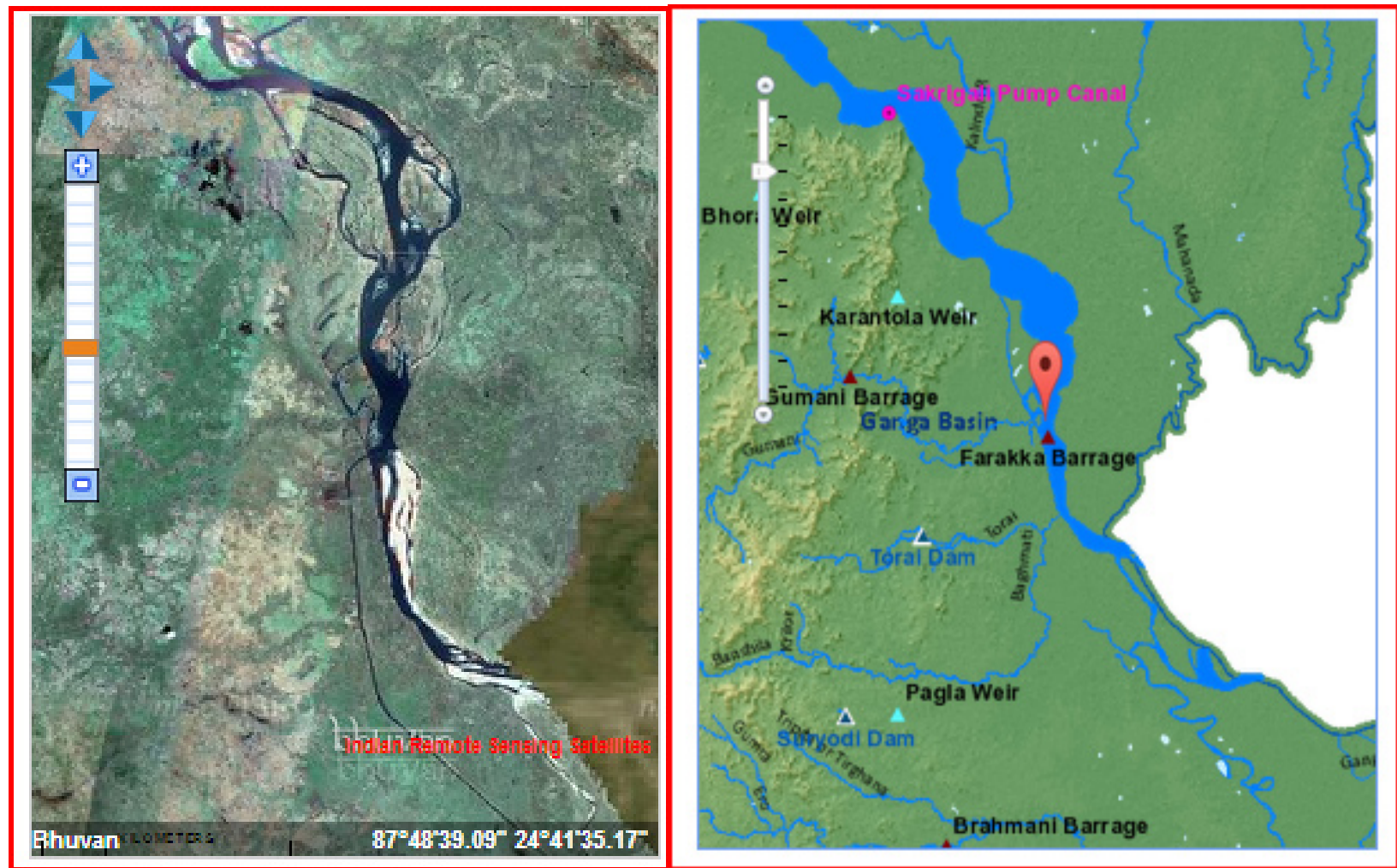

Fig4. Left inset: The Farakka Barrage across the Ganges and the pre-historic canal-like offshoot turned into the perennial feeder canal on the left side by India who claims the Ganges to have changed its course (http://indiawris.nrsc.gov.in/wrpinfo/index.php?title=Farakka_Barrage_B00639; right inset:. The location of the Farakka Barrage ((http://india-wris.nrsc.gov.in/wrpinfo/index.php?title=Farakka_Barrage_B00639)

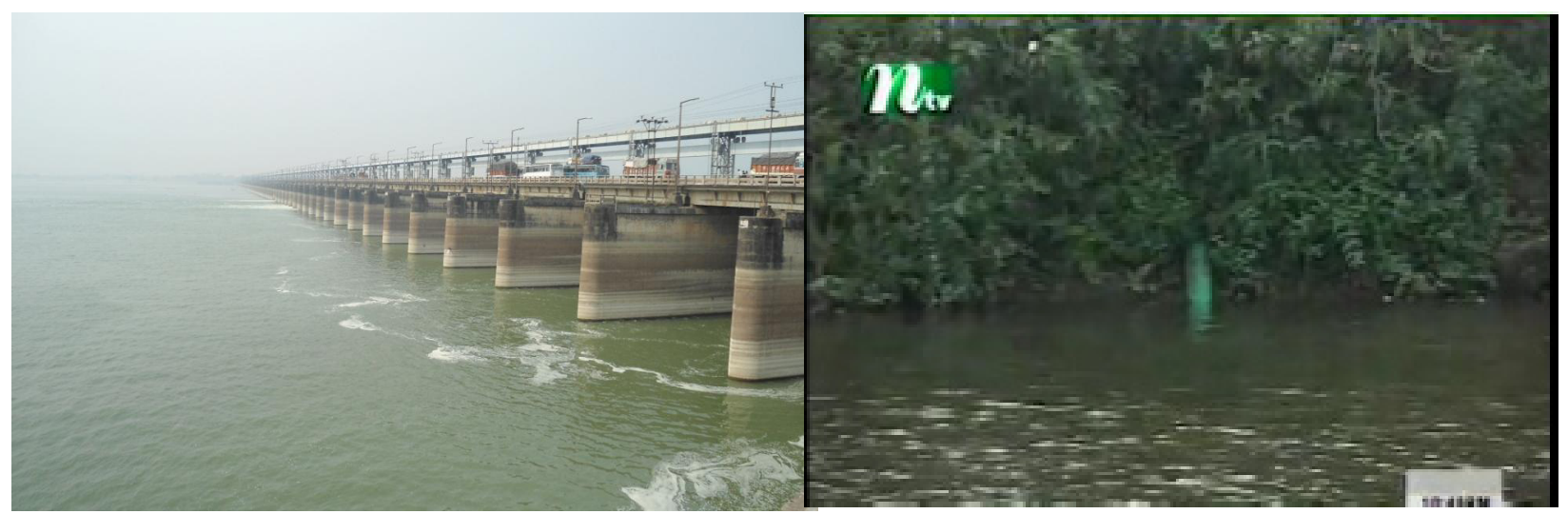

Fig. 5. Left inset: The Farakka Barrage (http://india-wris.nrsc.gov.in/wrpinfo/index.php?title=Farakka_ Barrage_B00639); right inset: India's water stealing from the border region Feni River through pipes set through the bush (Courtesy of ntv) 

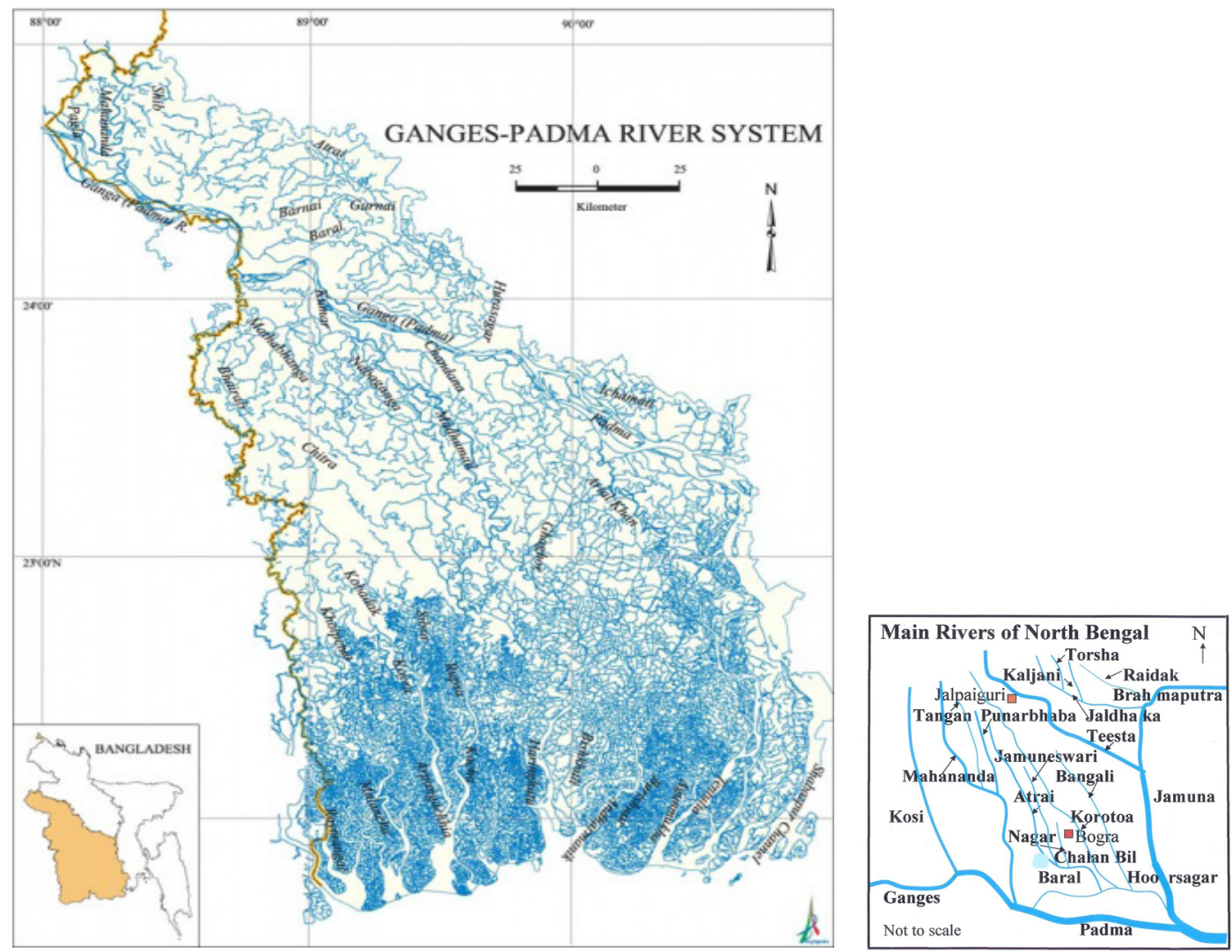

Fig 6. Left inset: The Ganges-Padma River system in downstream Bangladesh (courtesy of Banglapedia, http:// en.banglapedia.org/index.php?title=File:BasinGangesPadma.jpg); right inset: The Teesta sub-basin (P. K. Niyogi, http://en.wikipedia.org/wiki/Image:BD_Map_Rivers_of_North_Bengal.jpg)

India has built the Great Ring of Dams and Barrages (Fig. 3 )around the Bangladesh border like the natural ring of volcanoes in the Pacific Ocean. India holds the dry season flow through these rivers and release the excess flood season water to drain through Bangladesh causing her irreparable loss of lives and properties. India has been pirating the Ganges water through the Farakka Barrage (left inset in Fig. 5 and \#6 in Fig. 3), setup via many tricks (Adel, 2015a). The barrage has been the unique weapon to corner downstream Bangladesh. India excavated a pre-historic canal-like offshoot to pirate downstream Ganges basin ecosystem's water (Figs. 4). India calls it the changing of the course of the current Ganges through one of its old courses.

On top of being unfaithful to release water through the Ganges according to the treaty (Adel, 2015a, 2015b), she steals water using pumps and pipes from Bangladeshi rivers on the border (right inset in Fig. 5).

\subsubsection{Water Linkage to Economic Growth Blockage: Downstream Impacts}

The downstream affected areas in Bangladesh include the Ganges basin in the north-west of the country and the Teesta sub-basin in the north (Figs. 5A and 5B).

Water is the lifeblood of an ecosystem. It founds and maintains it. Reduction in the supply of the sustaining water has collapsed the Bangladesh ecosystems through a series of interconnected effects enumerated below. 
American Research Journal of BioSciences (ARJB)

3.1.1.1 Navigability Loss due to Water Piracy. Bangladesh lost a huge expanse of inland navigability (Table 1).

Table 1: Navighability Loss in Bangladesh

\begin{tabular}{|l|l|l|l|}
\hline River & Route & Distance $\mathbf{( k m})$ & Dry Ssn. Depth (m) \\
\hline Ganges & Godagari-Aricha & 209 & 1.75 \\
\hline Ganges & Aricha-Chandpur & 139 & 2.50 \\
\hline Baral & Origin-Confluence & $>100$ & Dry \& water-logged \\
\hline Musa Khan & Origin-Confluence & About 30 & Dry \\
\hline Garai & Talbaria-Kamarkhali & 70 & Dry \\
\hline Madhumati & Kamarkhali-Halurhat & 160 & Dry \\
\hline Atharabanki & Manikdaha-Rajapur & 40 & Dry \\
\hline Kaligana & Kustia-Sailkupa & 40 & Dry \\
\hline Kumar & Sailkupa-Alamdanga & 65 & Dry \\
\hline Nabaganga & Jhenaidaha-Bardia & 100 & Dry \\
\hline Mathabhanga & Gangni-Jhenaidaha & 70 & Dry \\
\hline Old Kumar & Ambikapul-Char Magura & 100 & Dry \\
\hline Kumar & Ambikapul-Manikdaha & 105 & Dry \\
\hline Chitra & Narail-Gazirhat & 28 & Dry \\
\hline Arialkhan & Chowdhurihar-Saheberhat & 95 & $1.50-1.00$ \\
\hline Bhairab & Khulna-Noapara & 35 & 1.75 \\
\hline Bhairab & Noapara-Raita & 295 & Dry \\
\hline Atai & Khulna-Narail & 25 & 1.00 \\
\hline Bil & Route Sindiaghat-Gopalganj & 45 & 1.00 \\
\hline Arialkhan & Route Sindiaghat-Jajira & 35 & 1.00 \\
\hline Kabodak & Taherpur-Pikegasa & 70 & Dry \\
\hline Bhadra & Monirampur-Chalna & 32 & Dry \\
\hline
\end{tabular}

Courtesy: BIWTA-Bangladesh Inland Water Transport Authority (slightly modified by inclusion of the left-over rivers from the northern part)

\section{Musa Khan's Lost Role}

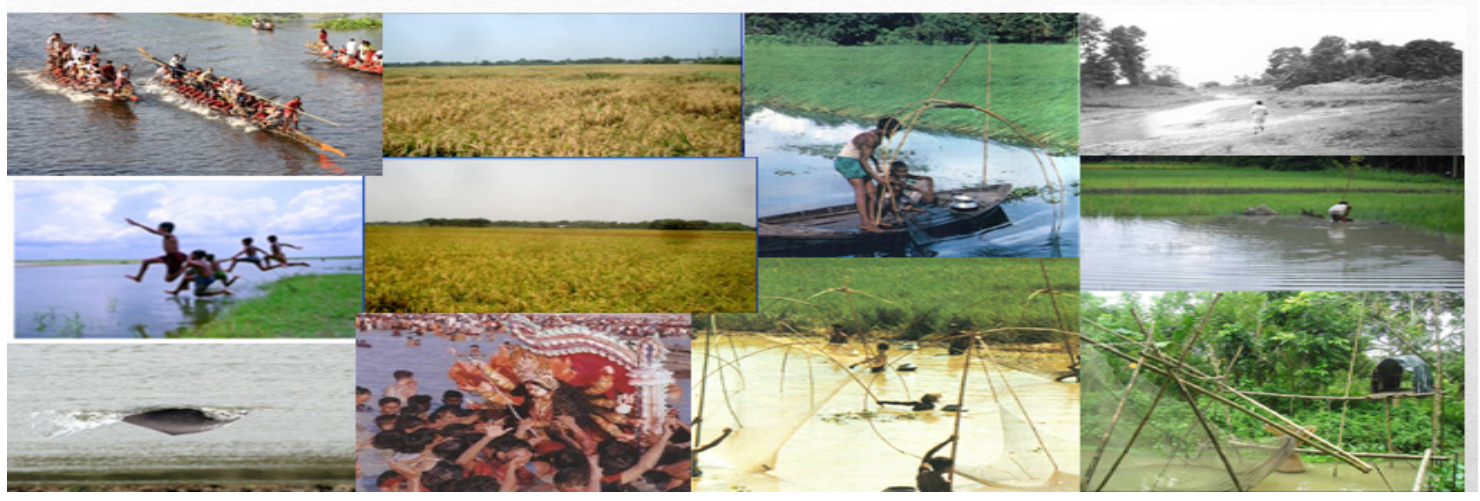

Fig 7. Activities that the Musa Khan (a secondary distributary of the Ganges) basin supported prior to 
The med_seventies (In courtesy of the contributors of the pictures taken from elsewhere to show the live Musa Khan activities). Counting from the left to the right in each row, boat racing, rice field, deep water fishing in a boat, shallow water fishing with bamboo strip-made fishing weapons (above it is the actual picture of the dead Musa Khan River), playful boys jumping in water for swimming, rice field, the extinct Gangetic dolfin, statue plunging in water by the Hindus, fishing with net, fishing with nets while spending night above water in a shelter.

No Ganges water has flowed in the Musa Khan since the late seventies. About 60 canals would feed hundreds of ponds, ditches, and about $900 \mathrm{sq} \mathrm{km}$ of floodplains in its heyday. All aquatics and amphibians in about 20,000 x $12 \mathrm{x}$ 3 cu m during Novvember-June and in about 20,000 × $100 \times 10$ cu m during July-November are gone forever before the preparation of an inventory. All dead distributary basins have been faced with similar situations.
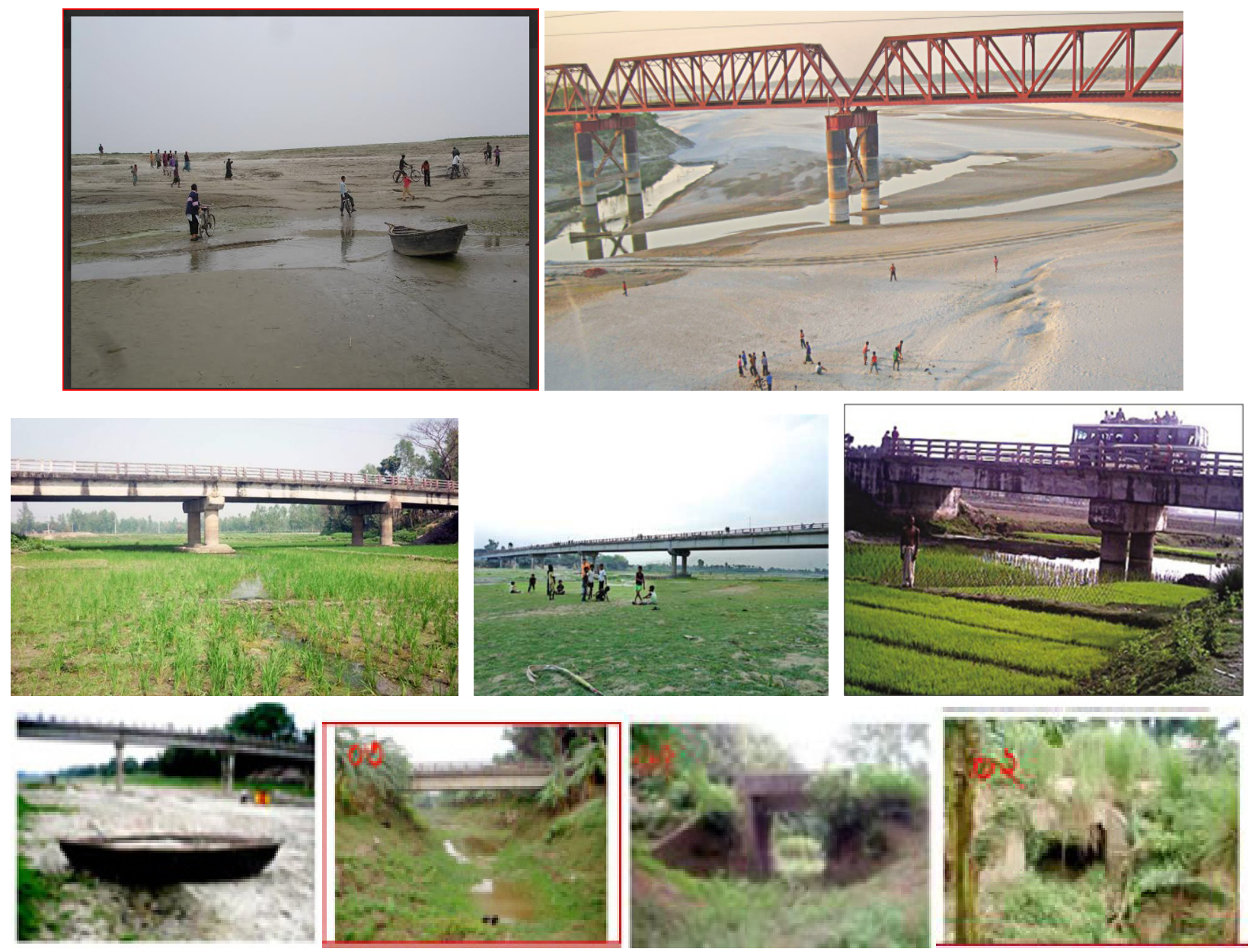

Fig 8. Top row from the left:The dry bed of the world's 8 th largest river Ganges beside Rajshahi. By Donald Katz, the EngineerRower in Bangladesh , 2008, available at http://donnybangla.blogspot.com/search/label/Rajshahi\%20 University); The dry bed of the Garhai, the lifeline of the northwest pat of Bangladesh (Courtesy of The Daily Starr, 12:02 am Tuesday, October 21, 2014). Middle row from the left : Green Riverbeds Emerge as Rivers Die, Tuesday, May 14, 2013, Mehedy Hasan, Rangpur Photo STAR; Jamuneshwari River in Nilpamari (http://www.thedailystar. net/news-detail-74864). Bottom row from the left: The Baral River (the Ganges's primary distributary), the Musa Khan River (the Baral's distributary), some two of 60 canals that the Musa Khan used to feed inland surface water resources prior to 1975. 
Table 2. Downstream Lost Waterways (BITWA, 2014)

\begin{tabular}{|l|l|l|l|}
\hline Year & Wet Ssn. Length $(\mathrm{km})$ & Dry Ssn. Length $(\mathrm{km})$ & Dry Ssn. Length $(\mathrm{km})$ \\
\hline 1971 & In tact & In tact & 24,000 \\
\hline 1984 & 8,400 & 5,200 & 13,600 \\
\hline 2010 & Lost & ------- & 15,600 \\
\hline & Risky & ------- & 3,300 \\
\hline
\end{tabular}

Source: BIWTA

It is to be noted that transportation on water ways are a few times cheaper than that on the land.

The closure of a few-times-cheaper inland waterways than the land transportation and increased pressure on land transportation causes a number of fatal accidents almost on a daily basis as reported in the country's news media.

The inland waterways had been a natural resource. The government investment cannot restore the waterways for the lack of surface water even if she diverts resources from a profitable sector to the excavation of waterways. The loss of water ways has affected inland trade and consumer transportation.

In the pre-piracy period, all floodplains turned into public fish breeding and raising sources resulting in brisk consumer consumptions.

\subsubsection{Extreme Climate Generation}

The South Asian country Bangladesh has been hard-hit by the generation of extreme climate due to the decades-long upstream Indian water piracy (Miah, 1989; Adel, 1999, Adel, 2000a, 2001, 2002) that has almost depleted the surface and groundwater in the north and the northwest. Her virgin inland seasonal and perennial shallow and deep water bodies were storing annually about 18 million trillion calories of heat (Adel et al., 2014 and the references therein). In the absence of this heat storage winters become unbearably cold and summers extremely hot. A partial list of these victims are provided in table 3. People use the groundwater massively (Fig. 10) to compensate for the surface water. Actually, the groundwater irrigation coverage increased from 6 to $75 \%$ in Bangladesh during 1980-2000 (BADC, 2002).

Table 3. Water shortage-generated extreme climate-related fatal and morbid cases (Adel et al., 2014)

\begin{tabular}{|l|l|l|l|l|l|}
\hline Year & Max $/$ Min $^{~} \mathbf{F}$ & Region & District & Fatalities & Morbidities \\
\hline $\begin{array}{l}2002 \\
\text { Bushfires, 2003) }\end{array}$ & 106.5 & NW & & 42 & \\
\hline $\begin{array}{l}2004(3) \text { News24 } \\
\text { Archives, (2004) }\end{array}$ & 105.8 & NW & Rajshahi & 47 & \\
\hline BNA (2005) & 109.4 & NW & Rajshahi & 35 & \\
\hline AHW (2007) & 104 & NW & & at least 26 & 200 \\
\hline AFP (2009) & 108 & Central & Dhaka & at least 16 & 40,000 \\
\hline $\begin{array}{l}\text { 2009 Kader and } \\
\text { Tribune (0000) }\end{array}$ & 108 & NW, SW & $\begin{array}{l}\text { Rangpur, Rajshahi, Jes- } \\
\text { sore, adj }\end{array}$ & at least 8 & \\
\hline Tong (2011) & 96.8 & Central & Dhaka & & \\
\hline
\end{tabular}

Volume 3

Page 8 
American Research Journal of BioSciences (ARJB)

\begin{tabular}{|c|c|c|c|c|c|}
\hline & 100.4 & SW & Jessore & & \\
\hline \multirow[t]{3}{*}{ SC, 2013} & 106.7 & SW & Chuadanga & & \\
\hline & 106.7 & NW & Rajshahi & & \\
\hline & 98.6 & Central & Dhaka & & \\
\hline LAT (1995) & 39 & NW & & 102 & \\
\hline Adel (1999a; 2000) & NW, SW & & & & hundreds \\
\hline Reporter (1998) & NW, SW & & & & 2,000 \\
\hline UCA (2003; 2003) & NW, Cntrl, SW & & & 750 & 300/day \\
\hline \multicolumn{6}{|l|}{ Clarke (1972) } \\
\hline 2006 (AP, 2003) & 46.4 & NW & Dinajpur, Ishwardi & 40 & \\
\hline BDREFB (2007) & 47.5 & NW & Rishahi & 141 & $2 \times 10^{6}$ \\
\hline DREF (2010) & 39.2 & NW, SW & & 135 & \\
\hline $\begin{array}{l}\text { Jan,'11 (Asiaone, } \\
\text { 2001;Reliefweb, } \\
\text { 0000; DREF, 2011) }\end{array}$ & 37.4 & NW & Syedpur, Qurigram & 11 & Thousands \\
\hline Kelley (2012) & NW & & Panchgarh, Qurigram & 10 & Hospital-full \\
\hline $\mathrm{ABC}(2013)$ & 37.4 & NW & Dinajpur, Syedpur & 80 & \\
\hline \multirow[t]{2}{*}{$\mathrm{RC}, 2013$} & 53.6 & NW & Rangpur & & \\
\hline & 14 & & & & \\
\hline
\end{tabular}

Apart from the account presented in table 3, in 2013, during 48 hours between 27 December midnight and 28 December noon 14 children died in northern district Rangpur Medical College (Fig. 9) due to cold-related diseases like asthma, diarrhea, pneumonia, etc. Most of them were infants, the oldest one being 2 years. One hundred more were being treated in the hospital. (http://bdnews24.com/bangladesh/2013/12/28/14children-die-of-cold).

People's sufferings and loss of lives coupled with income loss limit consumers' consumption ability that bring down GDP. The solution to these additional problems drain out profitable investments from other sectors.

The correlation between the Ganges water flow and the annual maximum and the minimum temperatures are -0.6 and +0.55 , respectively. The correlation of the summertime maximum and wintertime minimum temperatures have good moderate correlation with the declined river discharge. Also, moderate correlation exists between the HDD and the declined discharge (-0.47) and CDD and the declined discharge $(-0.49)$.

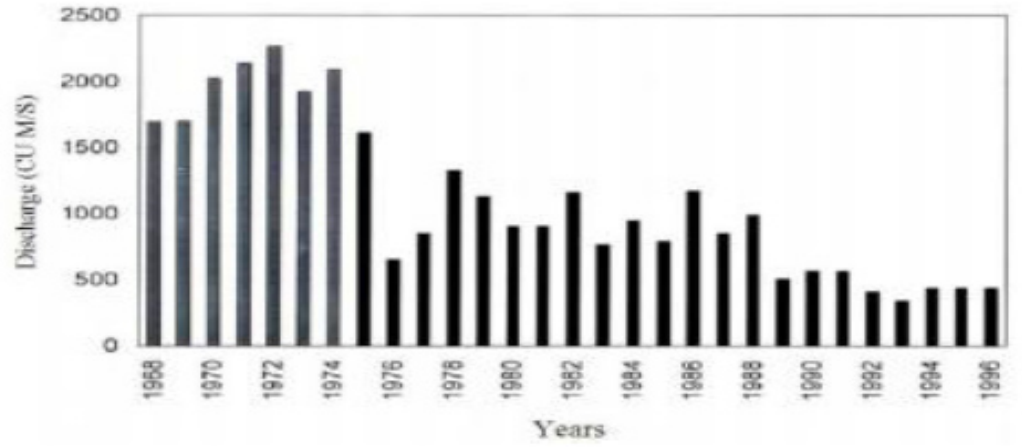

Volume 3

Page 9 

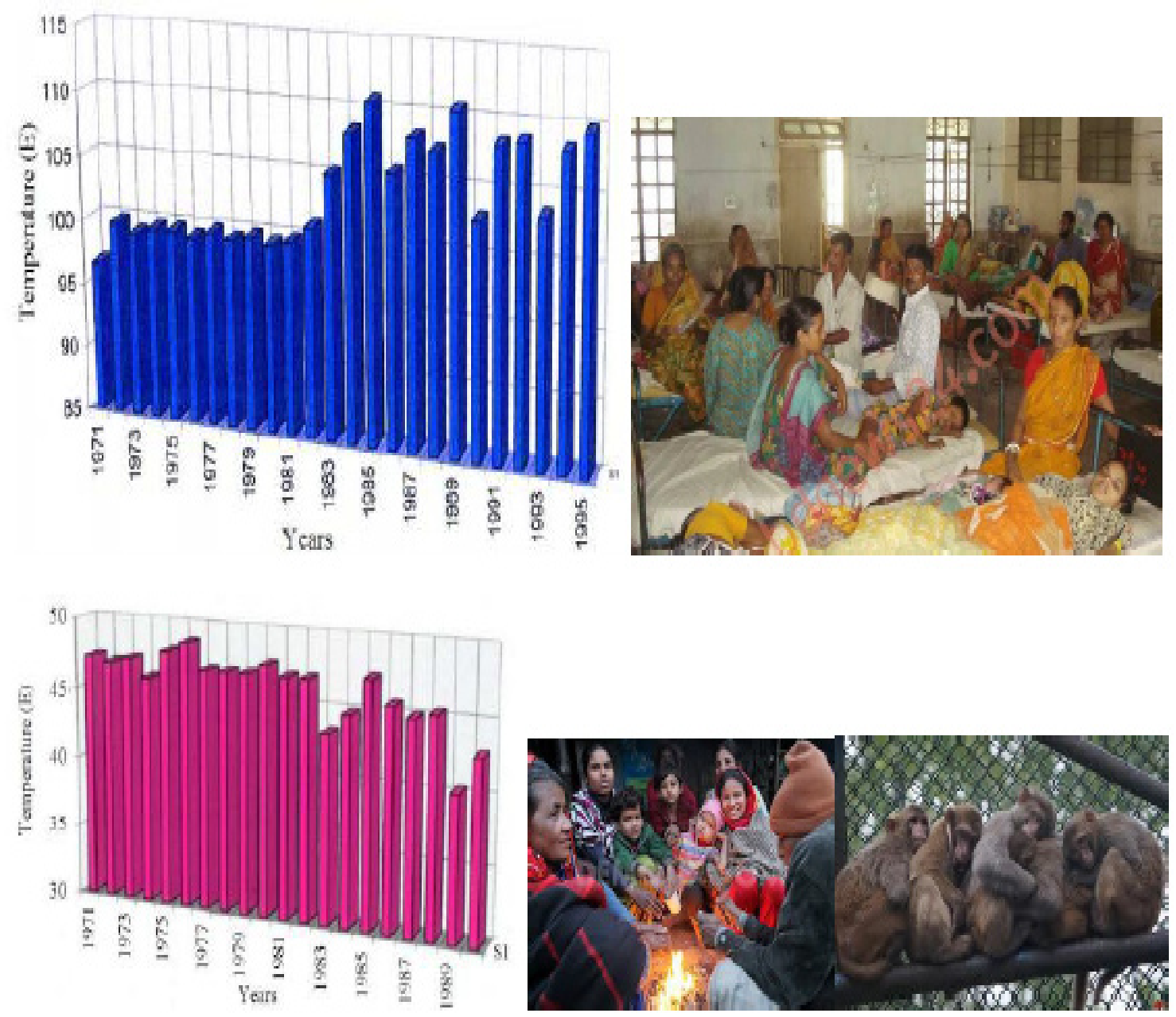

Fig. 9. From the top left to right: Water piracy contnued from the Bangladesh Ganges (Padma) River from 1975 through 1996; a sample of ncreasing the summer maximum temperature in the delta; children sick of diarrhea with their parents in Rangpur Medical College Hospital; a sample of decreasing wintertime minimum temperature; people use layerd cloths and kindle fire with straws to comfort; zoo monkeys are sticking to one another to get comfort. http://theextinctionprotocol.wordpress.com/2013/01/11/extremes-coldest-temperatures-in-nearly-50years-leave-80-dead-in-bangladesh-while-australia-bakes-in-record-highs/)

\subsubsection{Increasing Natural Calamities}

In Bangladesh, the probability of lightning-hit is one in 12,000 whereas in the USA it is one in 700,000. Deaths are occurring to people working in the field, on their way to get back goats and cattle from the field, going to pick mangoes, taking trips in open vehicles plying on land and waterways, making congregational prayers, etc. etc. In 2015, 274 people died. By May 2016, already, 189 died of lightning strikes. The fatalities in the month of May 2016 alone was 132. On 12 May 2016, 47 died (Amar Desh, 2016). 
In the absence of the heat-storing surface water bodies, this shelter-less heat supplies the due ingredient of hot and humid air for the formation of the lightning clouds the way illustrated in Fig. 11, the humidity being supplied by the hundreds of acres of flooded rice fields with groundwater The generation of extreme climate as a result of the depletion of the heat-absorbing and heat-retaining surface water bodies_has caused an increase of tornadoes and lightning-related fatalities and morbidities.
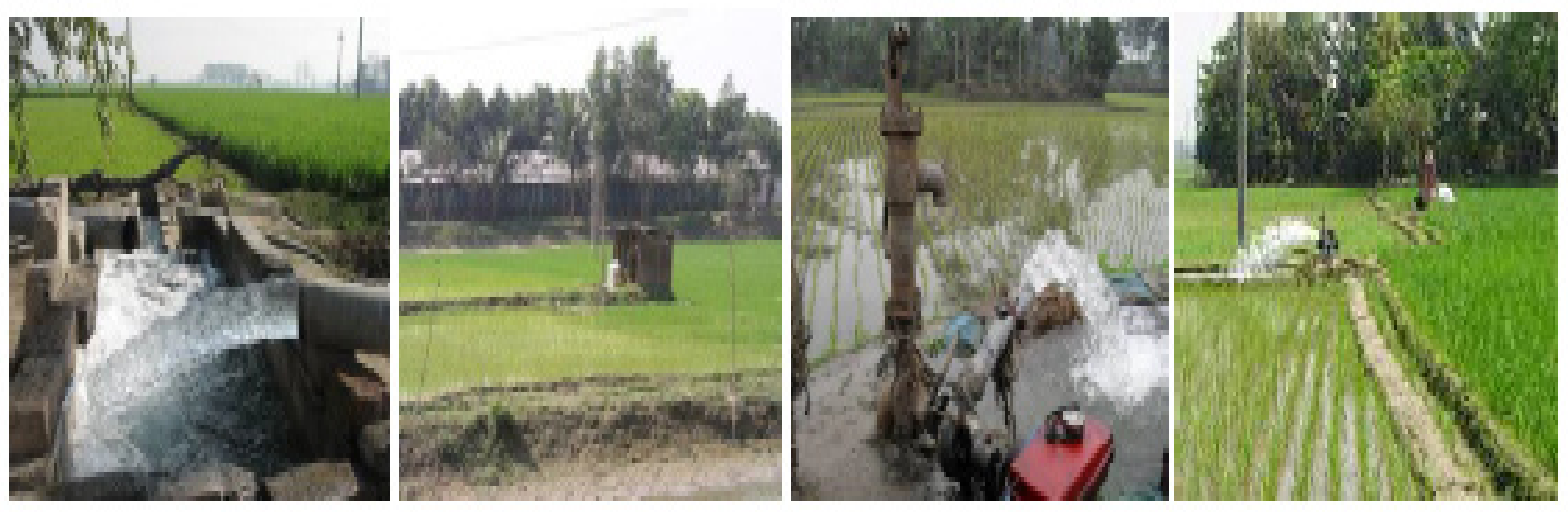

Fig10. Massive groundwater withdrawal to flood rice fields. (a) https://www.ucl.ac.uk/rdr/irdr/generalnews/groundwater-arsenic-pollution-bangladesh; (b) https://www.seed.abe.kth.se/en/om/avd/lwr/grupper/ forskningsomraden/egc/forskning/assessment-of-arsenic-and-manganese-in-the-rice-of-bangladesh-throughgroundwater-and-soil-1.295577; (c) https://www.google.com/search?q=image+of+groundwater+irrigation+in + Bangladesh\&espv=2\&biw=1920\&bih=955\&tbm=isch\&imgil=qJsHkc0FJZ5GkM\%253A\%253BOZW7B4Pga41r_M \%253Bhttp\%25253A\%25252F\%25252Fwww.sos-arsenic.net\%25252Fenglish\%25252Fsource\%25252F\&source $=i u \& p f=m \& f i r=q J$ sHkcOFJZ5GkM\%253A\%252COZW7B4Pga41r_M\%252C_\&usg=_i486XeYHdXIDZ77pu1GBEqeO alk\%3D\&dpr=1\&ved=0ahUKEwi9x-ac8MrNAhVm1oMKHQPDDzsQyjcINQ\&ei=0oJyV71C5qyPBIOGv9gD\#imgrc=j dS7aHEcqv7sXM\%3A; (d) http://www.thefishsite.com/articles/641/can-ricefish-farming-provide-food-securityin-bangladesh/

The way the lightning clouds form is illustrated in Figs. 11. The first step to grow cumulonimbus clouds is the formation of cumulous clouds. Hot humid air from irrigated ricefields goes up, cools down due to expansion under low pressure letting moisture to condense for the formation of clouds. Heat is released in condensation. As a result, it is warmer inside the cumulous clouds than the outside. The air inside the cloud is in agitation and the cloud rises up vertically. When the cloud rise to where the temperature is the freezing point of water, large water drops and hails are formed that precipitate to the ground. The falling rain, hails, evaporation, and cooling creates the downward trend.

In the mature stage, upward and downward movements work inside the cloud and starts intense lightning. The cloud rests at a height of the atmosphere at tropopause where it is calm. Lightning, heavy rain, hails, etc. etc. occur at this stage. Afterwards, the cloud breaks down. The frequency of the occurrences of the dangerous calamities has restricted peoples' movements related to fieldwork, business trips, and recreational activities. The productive use of time has been targeted for wasting unproductively. No investments can save from the calamities. On the contrary, the fatalities are causing the loss of manpower and people's earning means, and the hostile environment limits consumers movements. 

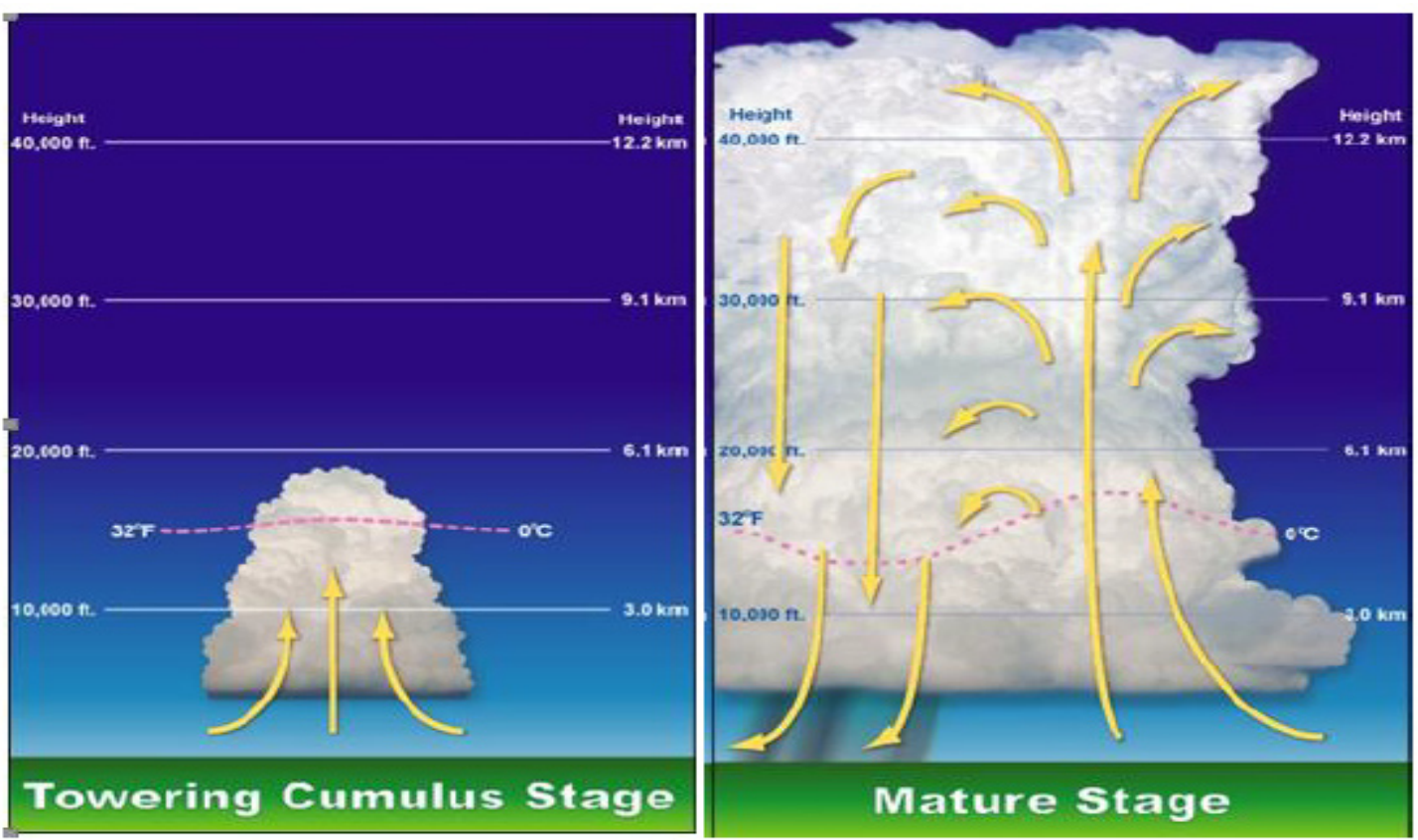

Fig. 11. Left inset: Formation of cumulous clouds (https://en.wikipedia.org/wiki/Cumulonimbus_cloud); right inset: The mature stage of cumulonimbus clouds (https://en.wikipedia.org/wiki/Cumulonimbus_cloud)

\subsubsection{The Loss of People's Nutritional Intakes}

There has been the loss of the cheap animal protein and calcium supplying fish source (Fg. 12) for more than one-third of the Bangladeshi population of 16 million because of the depletion of

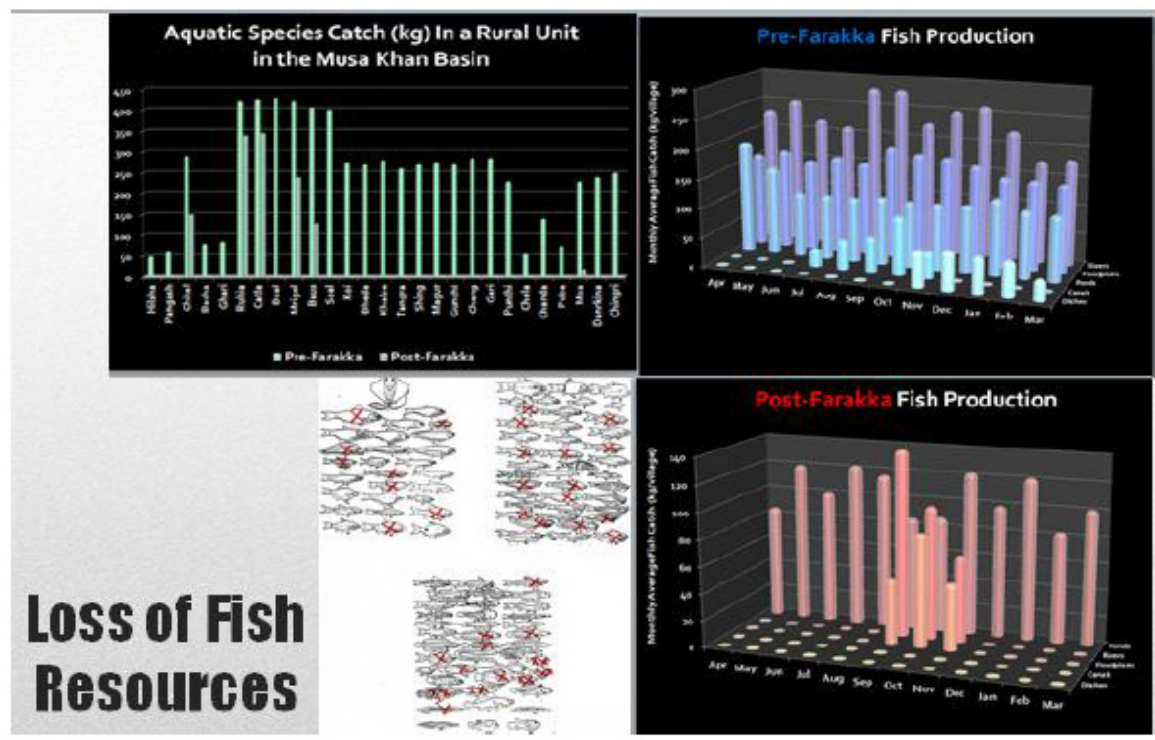

Fig. 12. From top left: Varieties of fish caught in the the pre- and the post piravy periods; pre-piracy period monthly fish production in a rural unit; the Gangetic fish varieties is about 102 many of which are extinct and endangered; fish catch in a rural unit during post-piracy period. 


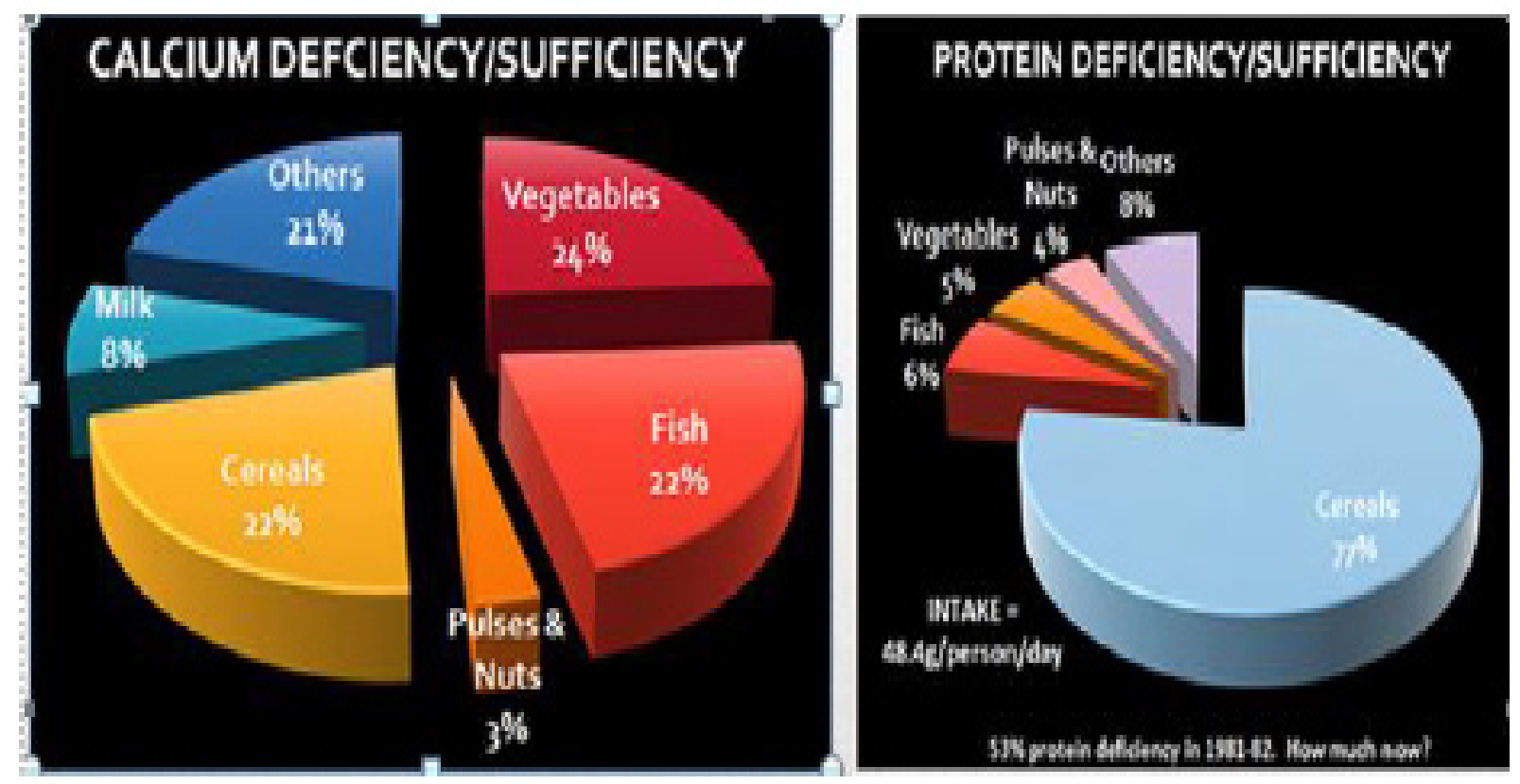

Fig. 13. Calcium and protein sufficiency and deficiency

the fish breeding and fish raising surface water resources. In early 1980s, calcium deficiency was more than $90 \%$ and protein deficiency was more than $50 \%$ (Fig. 13). Now fish is scarce and population has increased which predict broadening of the gap. In the pre-piracy period's 277,000 metric tons of fish production dropped to 185,000 metric tons in 1991. A recent survey shows that bulk of the rural families cannot taste fish in a month's time.

99\% of our bones and teeth is calcium. It is very important for growth and maintenance and reproduction. Prolonged calcium deficiency causes rickets, poor blood clotting, and in case of a menopausal woman, osteoporosis. Even young people complains of back pains these days.

The syndromes of protein deficiency are weight loss, subcutaneous fat decrease, weakness, muscle wasting edema, and fluid accumulation in serous cavities, hypotension ( low blood pressure) bradycardia (low heart beat), and pigmentary changes in the skin, and a drop in basal metabolic rate. Subcutaneous fat decrease cannot protect ill-clad at-risk population from losing body heat to succumb to death causing extreme winter-related fatalities.

People's productive lives are cut-short and/are made invalid. Both productions and consumptions are affected.

\subsubsection{The Arsenic Disaster}

The arsenic disaster in the Ganges delta is the world's worst man-made disaster (Adel, 1999a, 1999b, 2005, 2008a, 2013b). Arsenic-poisoning of groundwater due to the sinking groundwater 


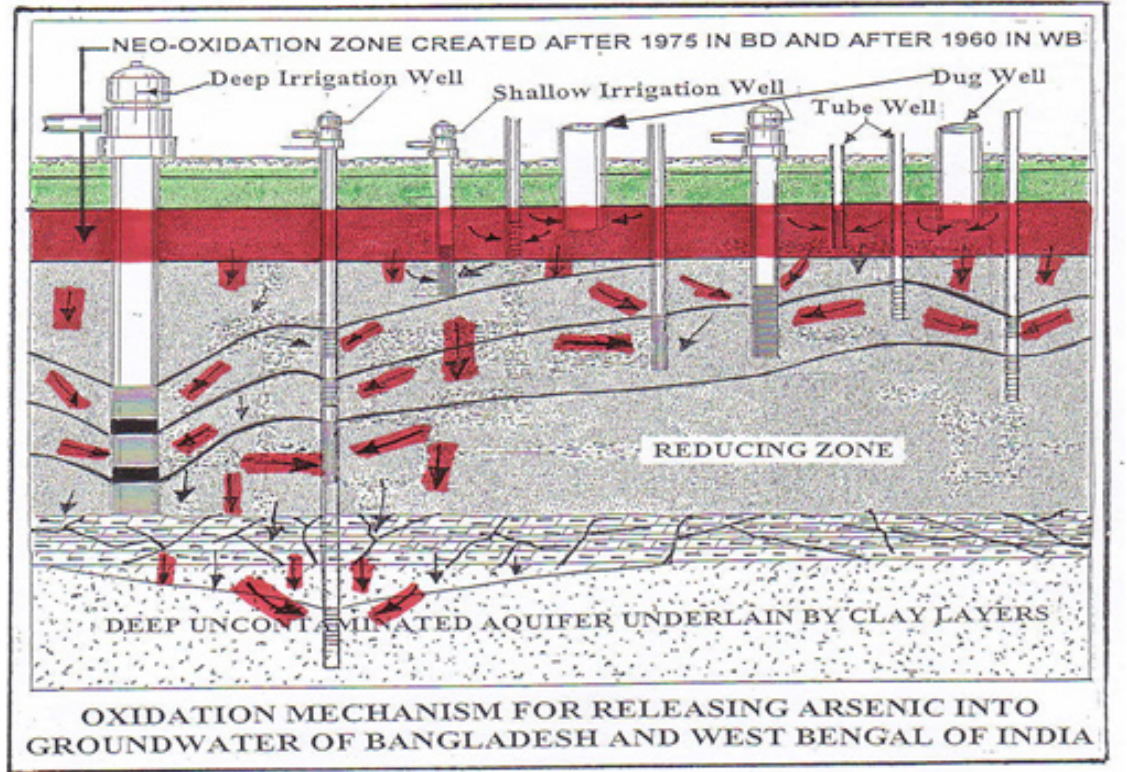

Fig 14. Illustration of the arsenic contamination of groundwater in the delta

table letting oxygenation of alluvium-buried arsenic compounds to form water-soluble compounds of arsenic and its infiltration to groundwater (Fig. 14). Fatalities and morbidities are very common due to the outbreak of arsenicosis. Also, a social instability of breaking off of families via a healthy spouse's divorcing/abandoning the spouse suffering from arsenicosis are of common occurrences (Fig. 15).
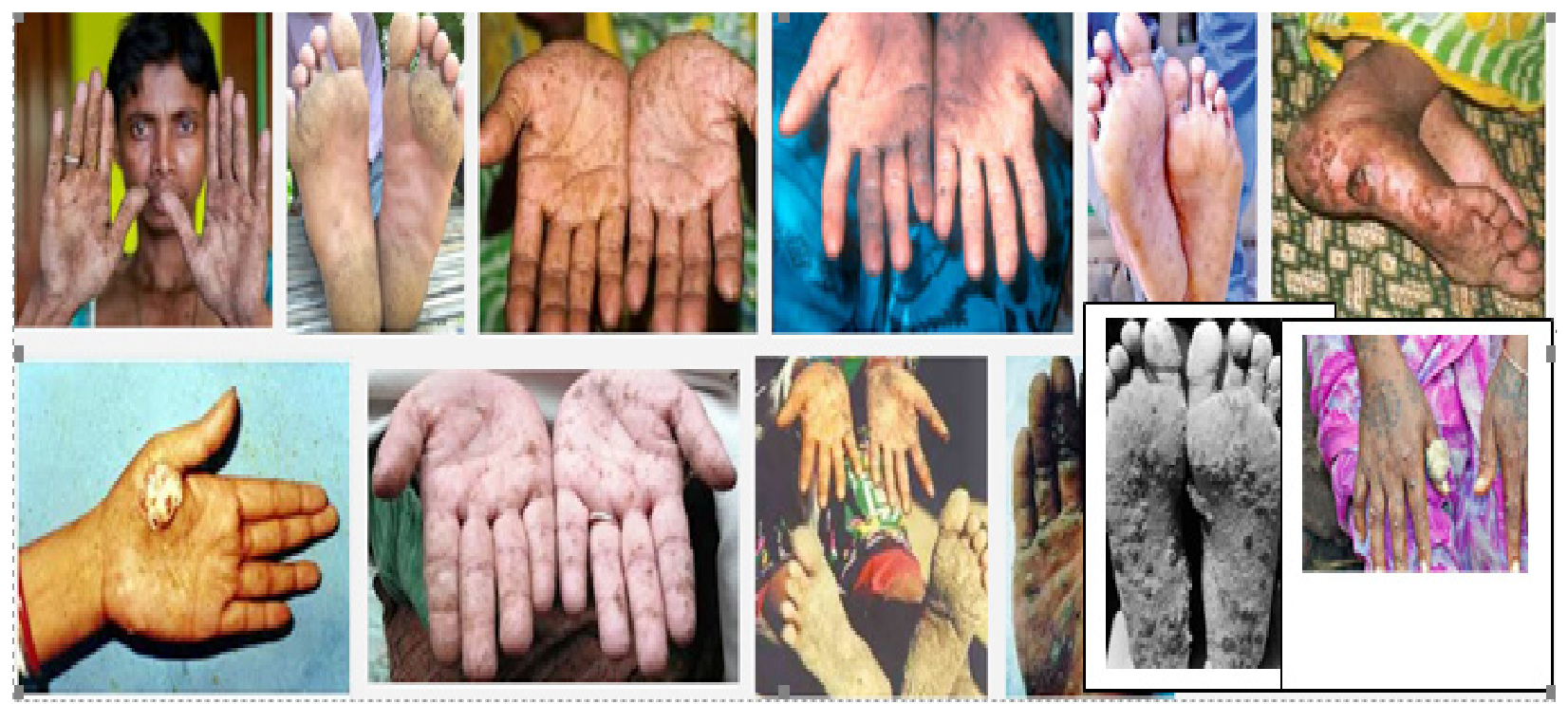

Fig 15. Some patients suffering from arsenicosis (Courtesy of https://www.google.com/search?q=image+of+ars enic + patients\&espv $=2 \& b i w=1280 \& b i h=649 \& t b m=i s c h \& t b o=u \& s o u r c e=u n i v \& s a=X \& v e d=0 a h U K E w j R m O e o z I r Q A h$ XGzVQKHTI2C-4QsAQIGg\#imgrc=F3J-x310jU-cjM\%3A) 


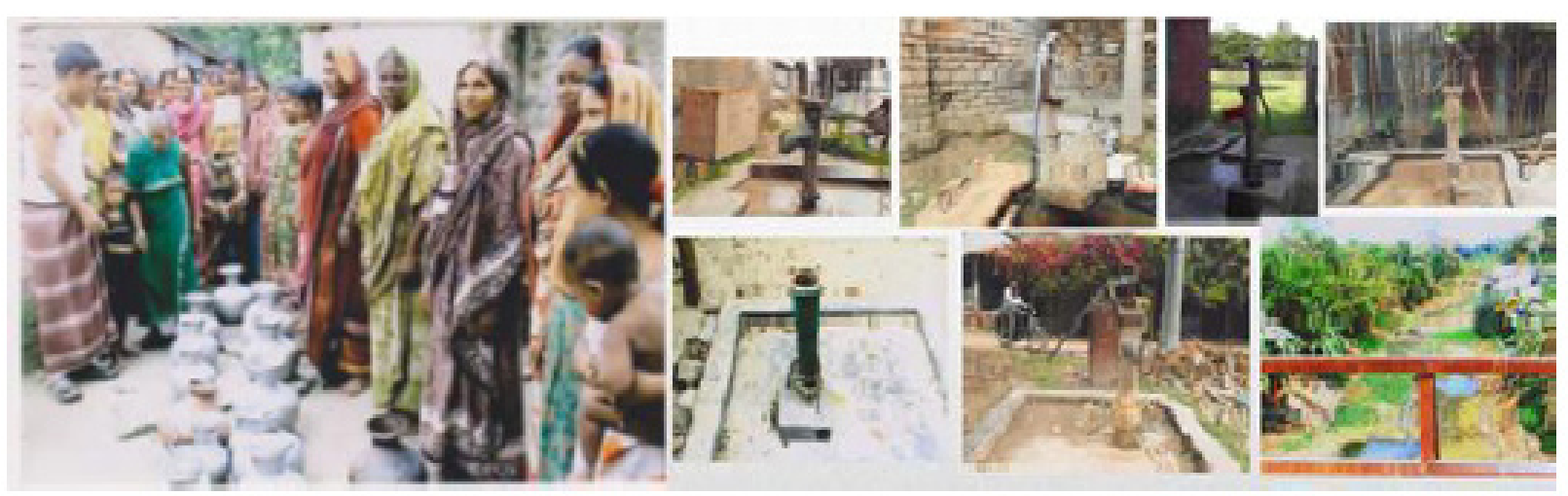

Fig 16. Women stand in que to get some potable water from the only arsenic-free tube well in the community whereas every household in community has got a tube-well (Photo: Samad).

There have been the international efforts to overshadow water depletion-caused groundwater arsenic contamination by directing research on the movement of arsenic to resemble the study of the movement of snakes when they are let out of the holes instead of closing the hole or to resemble study of the movement of bees when a bee-hive is disturbed.

Fig. 16 shows some of dozens of tubewells by the Musa Khan River bank that used to extract potable groundwater from a depth of $8 \mathrm{~m}$ in the pre-piracy period. Now, all of these extract arsenic-contaminated water during the piracy period. The rightmost inset is the dead Musa Khan River, the Ganges's secondary distributary River.

Arsenic is a poison. The USEPA and WHO recommend a dose of $10 \mathrm{ppb}$, Still then, pregnant and/or breastfeeding mothers exhibit disruption in their lipid metabolism, leading to diminished nutrients in their blood and in their breast milk. Their offspring showed significant deficiency in growth and development during their postnatal period before weaning (Drs. Hamilton and Koul-Horvath, Superfund Research Program at Dartmouth, 2012). Bangladesh has seta standard of $50 \mathrm{ppb}$. More than 75 million people are affected in Bangladesh. Astudy of 12,000 Bangladeshis conducted by the director of the Center for Cancer Epidemiology and Prevention, Univ. of Chicago Medical Center finds 20\% fatalities due to arsenic (http://www.uchospitals.edu/news/2012/20120223arsenic-toxicity.html).

Thus, the arsenic contamination of groundwater has been crippling the society which is the most downward trend of consumers. The recuperation is beyond the government spending and private/government investment. It is not favorable GDP increase.

\subsubsection{Random Disposal of Arsenic Sludge}

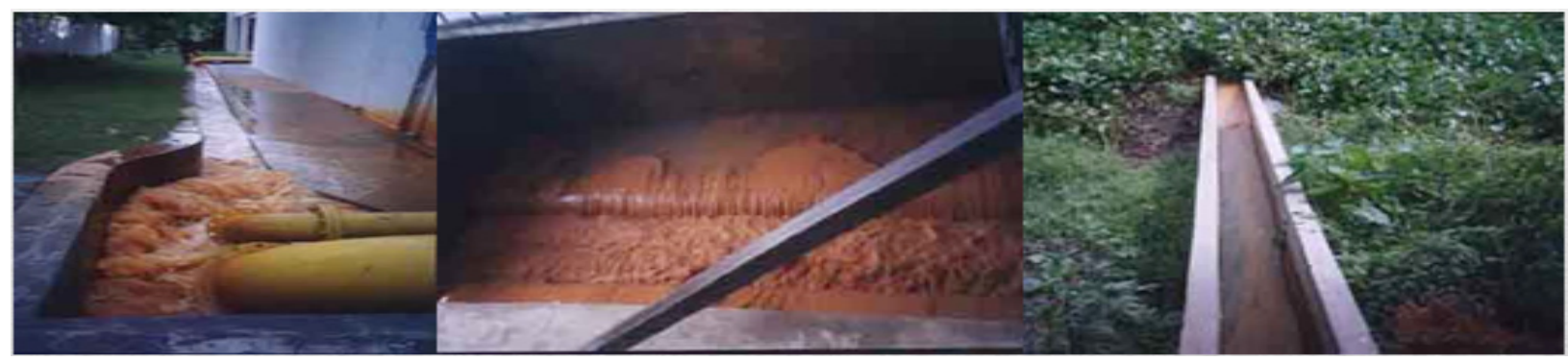

Fig. 17. Arsenic sludge disposal in river water 
The environmental degradation of randomly disposing arsenic sludge (Fig. 17) creates risks for cancers (Adel, 2013c; Adel and Husain, 2008, 2014). The irrigation with contaminated groundwater is causing arsenic entrance to the food chain. Future generations are on the verge of being crippled for drinking arsenic-contaminated water, breathing arsenic-contaminated air, and consuming arsenic-contaminated food stuff. Once again, the manpower, the key agent of consumption and main consumers are suffering. The calculation of GDP is losing its prominent factor.

\subsubsection{Groundwater Depletion}

The groundwater is being depleted doe to over-extraction of in the absence of adequate recharging. The groundwater exploitation exceeds its recharging because of the lack of river discharges coupled with low rainfalls (Miah, 1996a; Adel, 2003, 2008b, 2012a, 2012b) The scenario is illustrated in Figs. 18, 19, and 20. Groundwater is the last resort of a nation. A nation's balance of resource falls in the red having lost the surface water resources and the groundwater depleted. It will suffer from food insolvency and import deficiency. Nothing is left for improving the GDP.

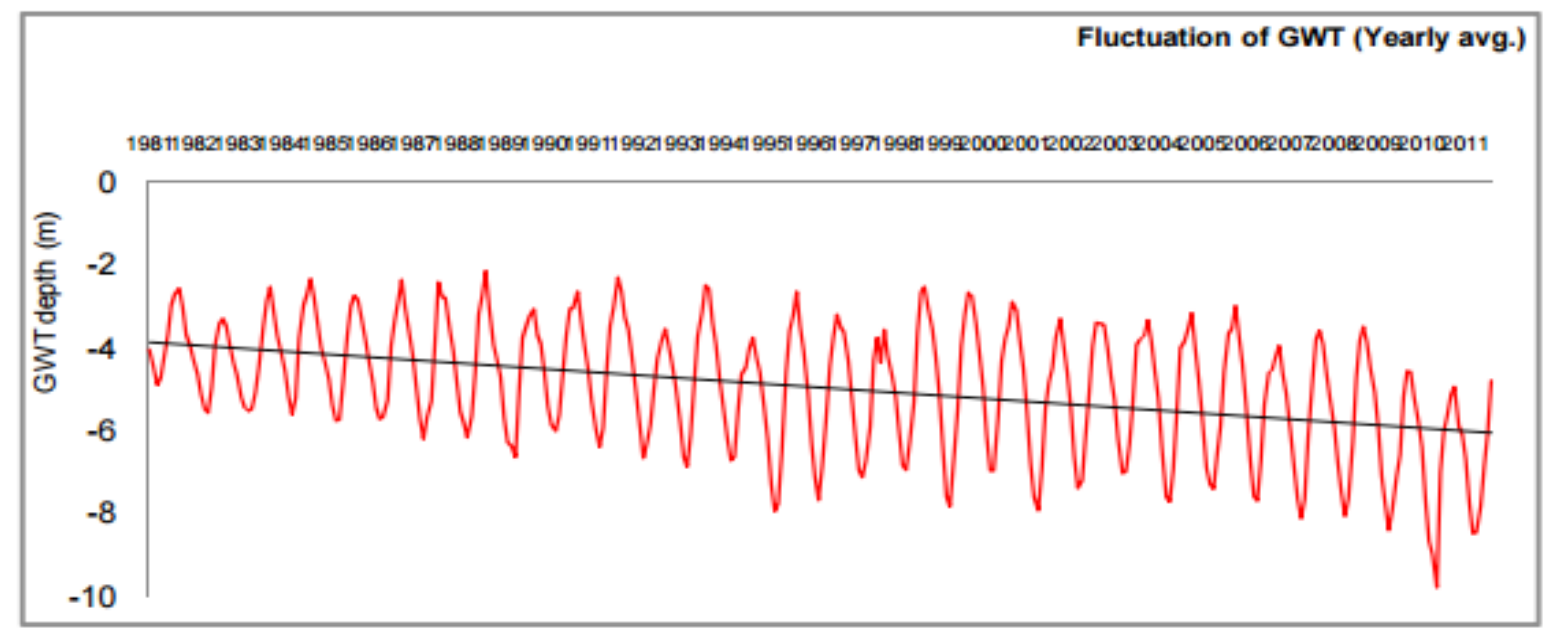

Fig18. A 30-year (1981-2011) declining trend of groundwater in northwest Bangladesh (courtesy of Dey et al., 2013)

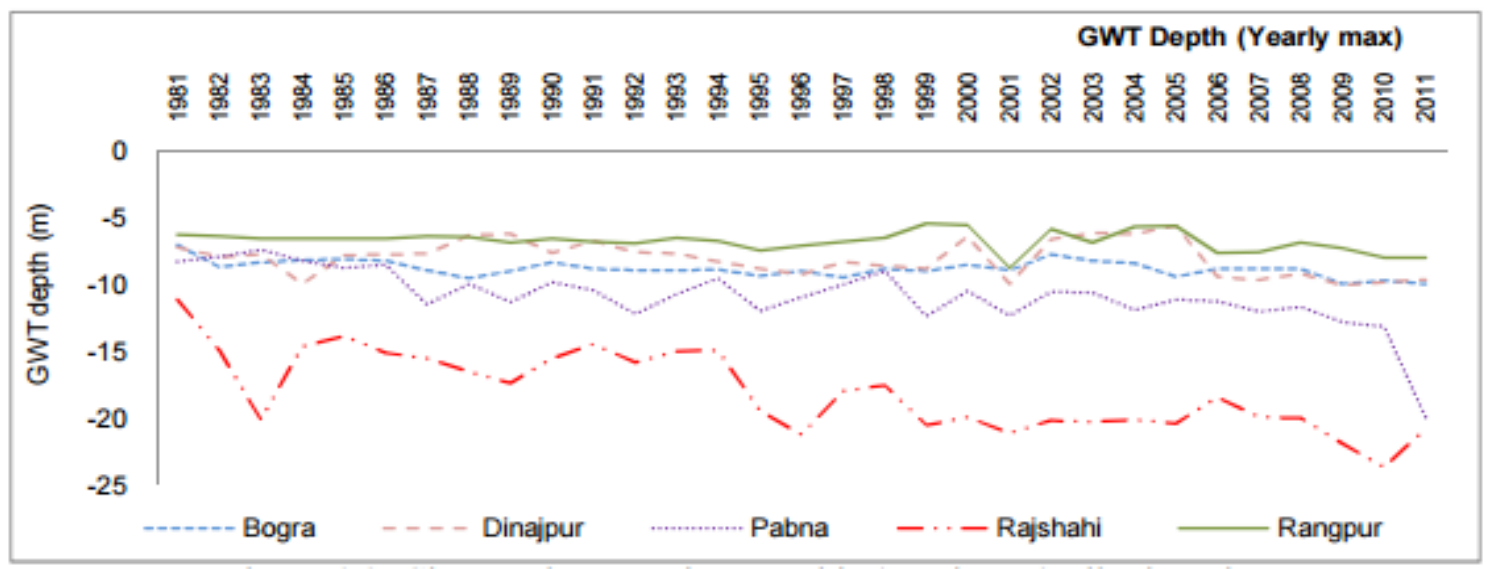

Fig. 19. District-wise dry season (January-May) maximum depletion of groundwater (courtesy Dey et al., 2013) 

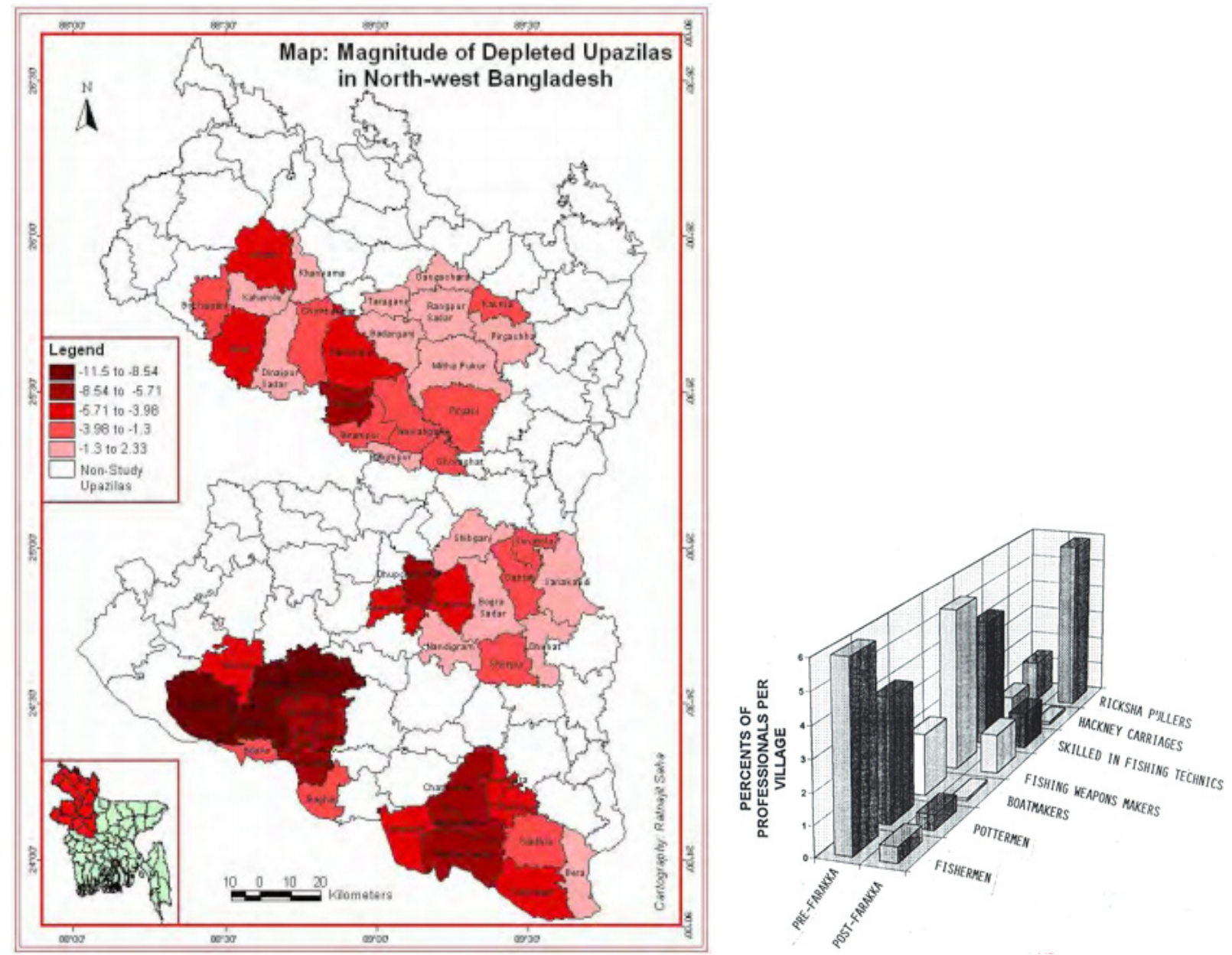

Fig 20. Left inset: Upozila-wise dry season (January-May) groundwater depth categorized as severe, moderate, medium, less depleted, etc. in the range of -2.3 to -11.5 m(courtesy of Dey et al., 2013); right inset: loss of livelihood in the Musa Khan River basin.

\subsubsection{Livelihood Loss}

In their golden days, fishermen population living by the Musa Khan River, would spend almost the whole year in boats, whereas in the pre-piracy period they do not get water today to take baths. A population of 150 fishermen would make 350 fishing nets of 20 different kinds (Adel, 2001, 2008c). The author found in a survey that the numbers of fishermen, pottermen, boatmakers, and fishing equipment makers dropped drastically from their $6,4,0.4$, and $5.4 \%$ to $0.5,0.5,0.08$, and $1.3 \%$ of the rural population in the dead Musa Khan basin (right inset in Fig. 20). Similar stories hold true in all dead distributary basins of the Ganges (Padma). While the UNDP promotes cottage industries to solve unemployment, generations-old net-knitting cottage industries are in oblivion now due to the upstream water piracy by India, the desirous candidate for the permanent membership at the UN Security Council. 


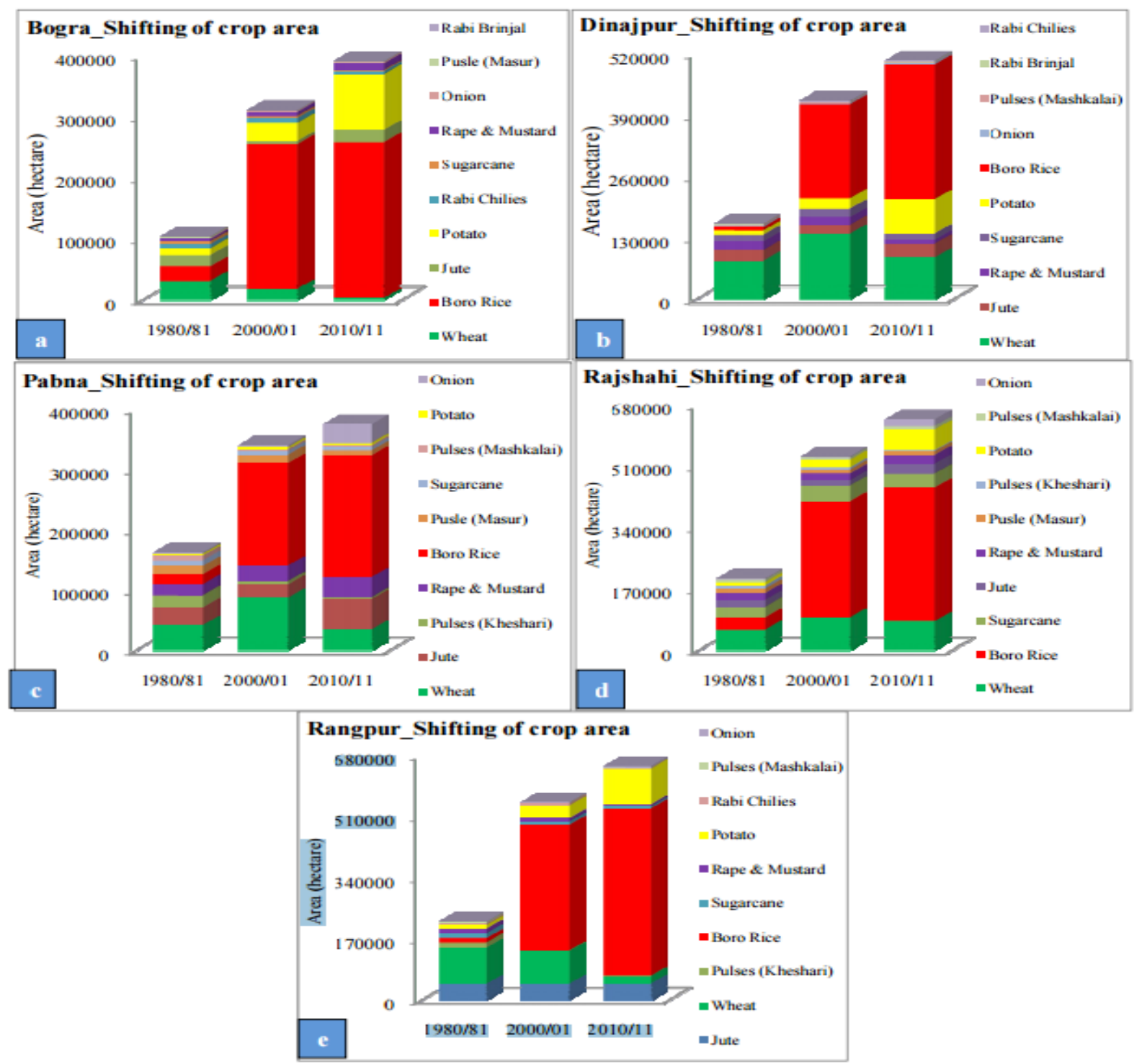

Figure 4.10 (a-e). Change in crop area over time in (a). Bogra, (b). Dinajpur, (c). Pabna, (d). Rajshahi, and (e). Rangpur district of northwest Bangladesh

Fig. 21. Shifting of major crop area over 30 years in northwest Bangladesh over the districts of (a). Bogra, (b). Dinajpur, (c). Pabna, (d). Rajshahi, and (e). Rangpur (courtesy of Dey et al., 2013).

\subsubsection{Species Extinction}

With the drying out of the surface water resources (Fig. 8), numerous aquatic and amphibian species before an inventory can be made (Adel, 200, 2012a, 2012b, 2013d). Wetland ecology has been turned into a dry land one. The Musa Khan used to have a spectacular scene with the playful Gangetic dolphins. Fig. 12 shows the extinction and endangerment of the Gangetic fishes. The void created by the loss of those unknown number of aquatics 
and amphibians has resulted in a loss of balance in the nature. These are irrecoverable for the government. It needs micro-economist researchers to finding out the pinching effect on the country's economy.

\subsubsection{Shifts in Agricultural Practices}

Farmers have changed their agricultural practices with the unavailability of the surface water bodies and taking resort to groundwater use (Miah, 1996; Adel, 2001). Fig. 21 shows the increase in the area under boro rice cultivation about 17 times more in 2010-2011 than in 1980-81. During that time the cultivation area of ten major crops - rabi brinjal, pulse (masur), onion, rape and mustard, potato, sugarcane, jute, wheat, and rabi chilies - increased only three times. Per square kilometer use of tubewells has increased five times from 6.9 to 36 with the number of deep tubewells (DTW) increase two times and shallow tubewells (STW) increase more than five times during 1984-85 to 2010-11. The number of tubewells increase was 8.5 times to serve irrigation over 1.6 times increased areas.

\subsubsection{Obstruction to Religious practices and in Recreational Activities}

Once again, it is an issue in the domain of microeconomics to enumerate the impact on the Hindu minority who got the obstruction to observe their festivals resulting in the plunging of statues in the Ganges water flowing through its distributaries in Bangladesh (Fig. 7, the $2^{\text {nd }}$ bottom inset from the left). Also, the loss of water sports and other recreational activities' natural facilities, and enjoyment of the aesthetic beauty of natural free-flowing and stagnant water bodies has affected people mentally (Adel, 2001). Fig. 7 shows the boat race and sportive young kids' jumping in water to swim. The new generation grow up with this void in their environment.

\subsubsection{Cracks and of Inclination of Large Structures}

The pressure of underground fluids water and gas balances the pressure of the overlying layer of the earth. If the fluid pressure is reduced, heavy structures on the surface tilt, crack, sink down etc.(Fig. 22). Structures that run risky after constructions or the sinking of historic relics do not contribute positively to GDP.
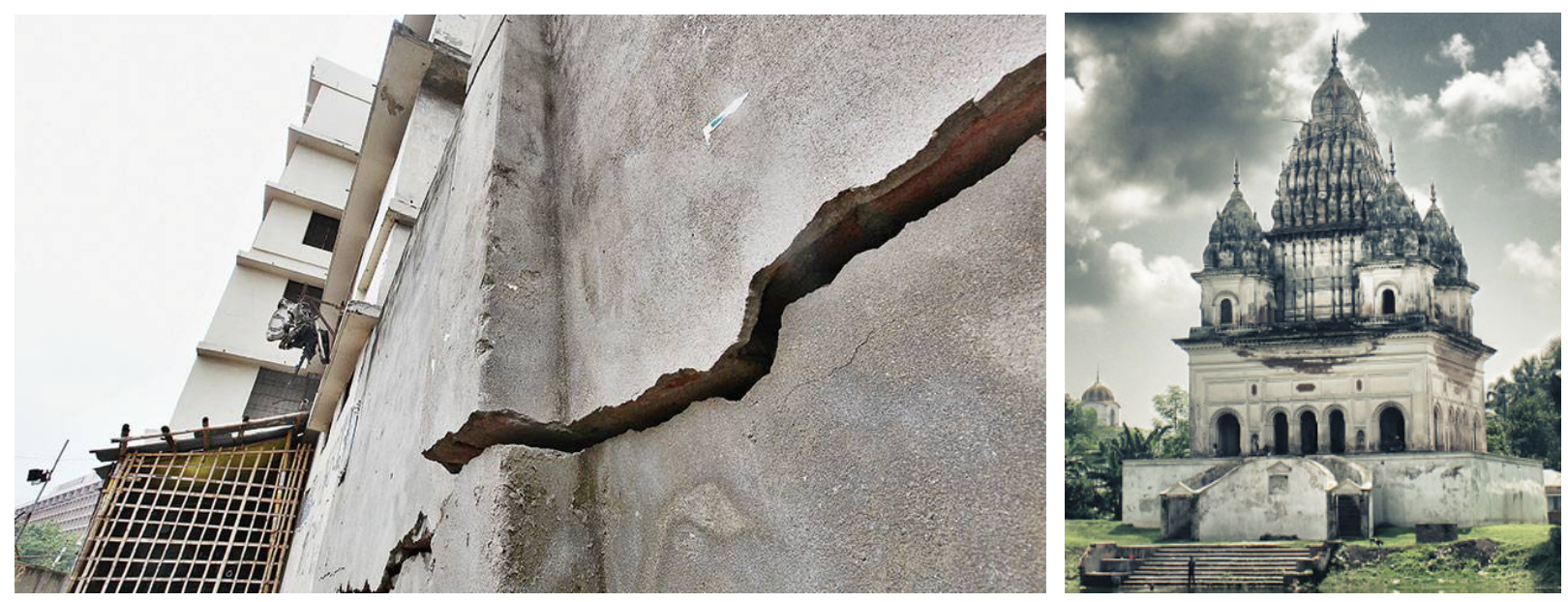

Fig 22. Left inset: Land subsidence puts the hotel building at risk (courtesy of K. Hasan, Dhaka Tribune, published: 02:17 may 28, 2015 - See more at: http://archive.dhakatribune.com/bangladesh/2015/may/28/land-subsidenceputs-hotel-building-risk\#sthash.BlhcpGDT.dpuf); right inset: The historic structure Shiva Temple at Puthia, Rajshahi (https://en.wikipedia.org/wiki/Puthia_Temple_Complex\#/media/File:Shiva_Temple,_Puthia,_Rajshahi_ NK_(2).jpg) is said to be sinking down. 


\subsubsection{Inland Intrusion of Saline water}

Inland intrusion of the saline waterfront in the wake of the weakened river current increases soil salinity and kills fresh water aquatics. Saline water causes health problem in pregnant women, and kidney diseases, and rheumatism in human, and affect milk productivity and reproductive health in cattle. Salinity causes scarcity of drinking water and declination in industrial production

Salinity affects growths of forest species. The Gangetic dolphins lost inland freshwater range. They cannot tolerate the coastal saline water.

Bangladesh coastal rivers total $24,000 \mathrm{~km}$ over an area of $9,380 \mathrm{sq} \mathrm{km}$. About $66 \%$ of coastal land is saline. Salinity covered 833,000 ha in 1973 , and 1,056,000 ha in 2009. 5,000 millimho engulfed 7,000 - 12, 000 sq miles, and 20,000 millimhos engulfed $5000-8000$ sq miles. Salinity attacked 45 million trees and plants in 2,200-sq miles wide Sundarbans in the nineties (Fig. 23). Salinity has affected the productive land resource and has decreased the net cropped areas along with destroying natural diversity and crippling population.

\subsubsection{Inland deposition of sediments and coastal erosion}

During 1976-1990, the entire coast lost $50 \mathrm{sq}$ km (SPARSO). Bhola (Fig. 24) lost $280.70 \mathrm{sq} \mathrm{km}$, Hatiya $77.58 \mathrm{sq}$ km, Sandwip $110.75 \mathrm{sq} \mathrm{km}$, Monpura $78.45 \mathrm{sq} \mathrm{km}$, and the Sundarbans $297.63 \mathrm{sq} \mathrm{km}$. Out of 794 million tons of the Ganges sediment, the Indian Hooghly coast receives 361 million tons ( 9 times more than Bangladesh), and Bangladesh just 40 million tons. This is very insufficient to resist the sea's natural tendency to erode the coast line. Indian Ganges floodplain receives 65 million tons and Bangladesh floodplain 328 million tons (five times more than India). This is enough for a quick silting of the Bangladeshi water bodies (Fig. 8).

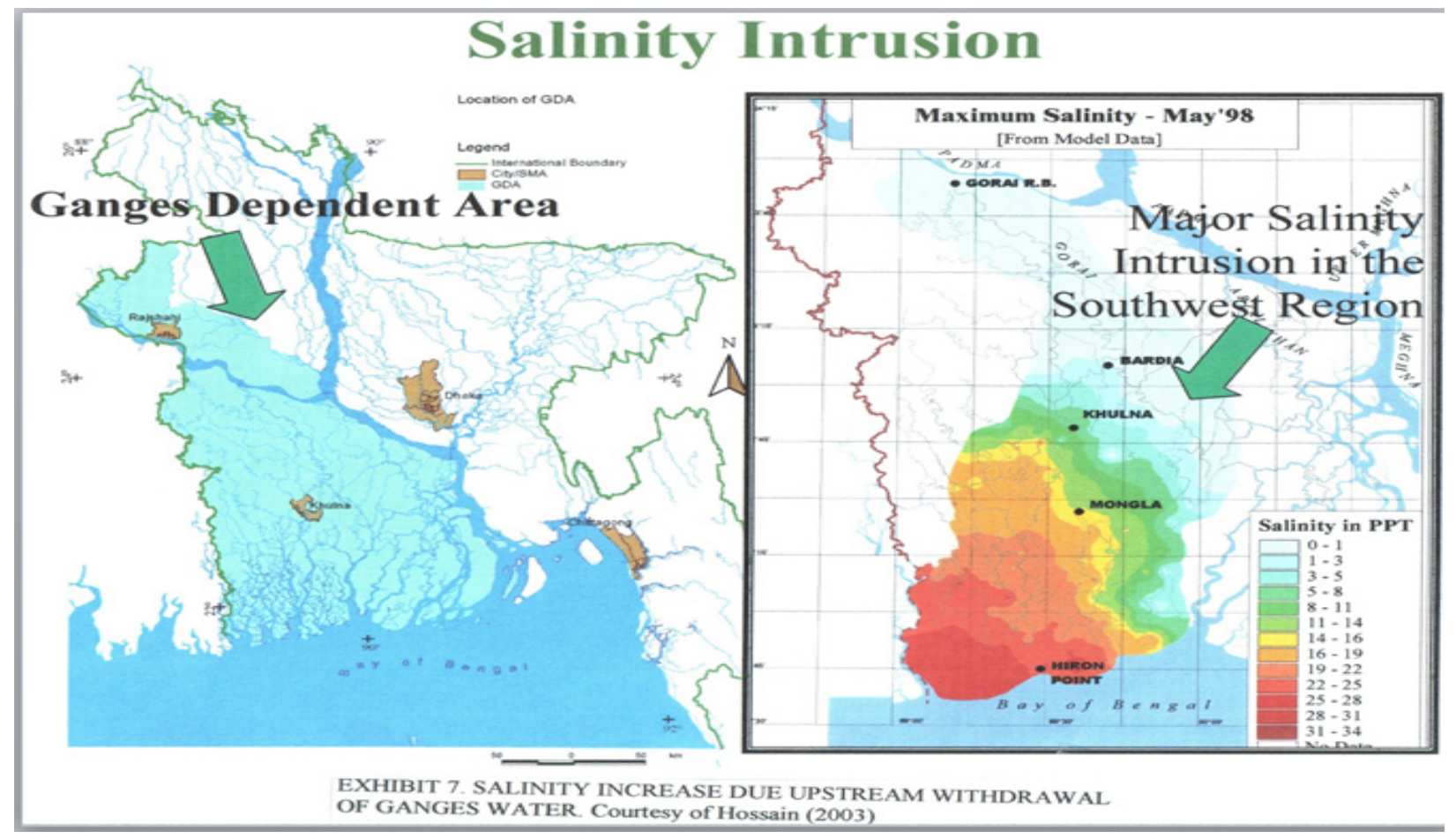

Fig. 23. Salinity intrusion (courtesy of Hossain, 2003)

Volume 3

Page 20 


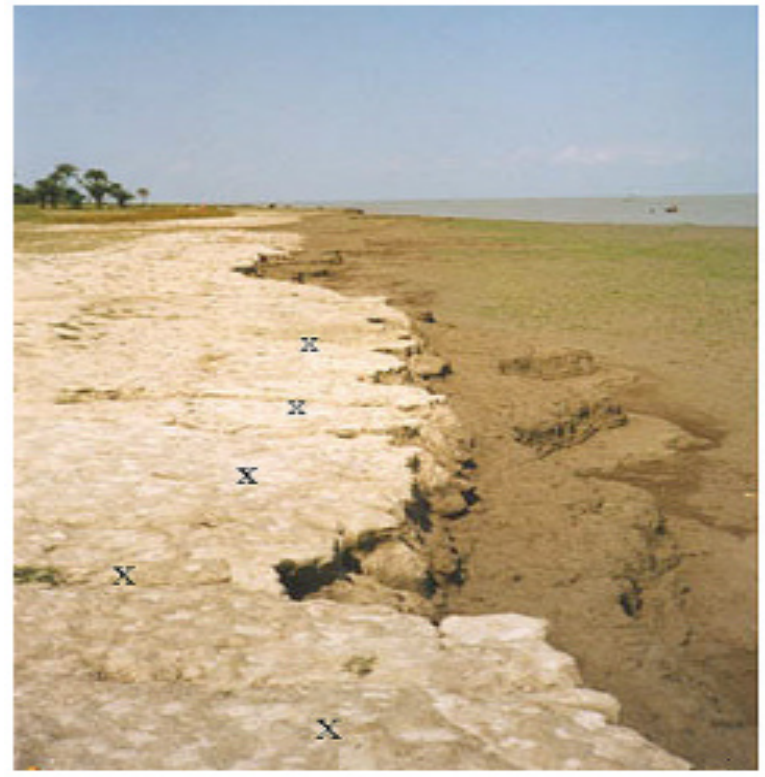

Fig. 24. Coastal Erosion on the Islan of Bhola (Krantz M, 1999)

\subsubsection{Devastating Floods}

Bangladesh suffers from the loss of lives and properties due to flooding as the sediment-filled riverbed fail to accommodate floodwater released from the upstream when the upstream cannot manage it.
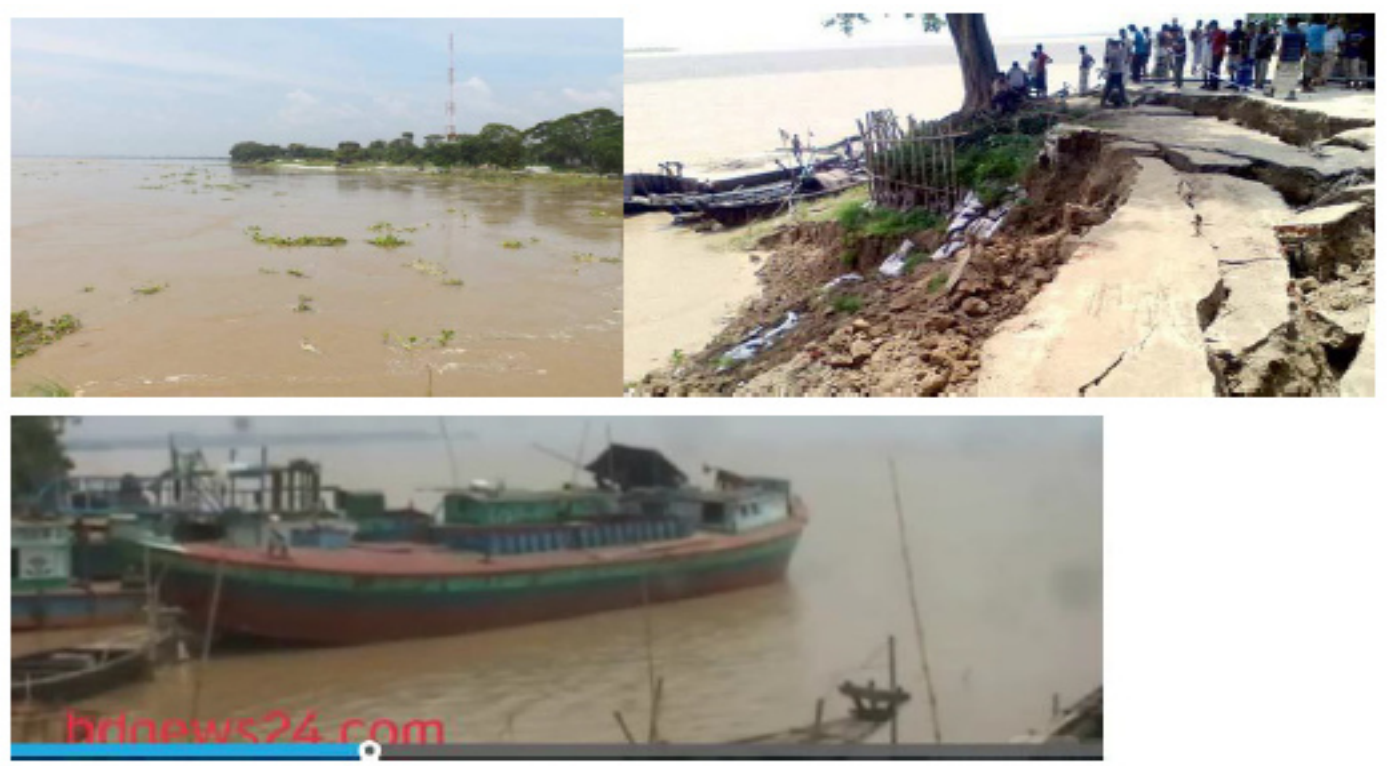

Fig. 25. Left and bottom insets: Padma bed shown in Fig. 9 is under water (http://www.risingbd.com/english/ photogalleryN.php, 2016) ; top right inset: Bangladesh losing land in Rajshahi due to the Ganges's erosion (Aug 7., 2016http://www.dailysangram.com/) India occupies and fishermen fail to ascertain the borderline which make them lose their traulers at the hands on Indian BSF 


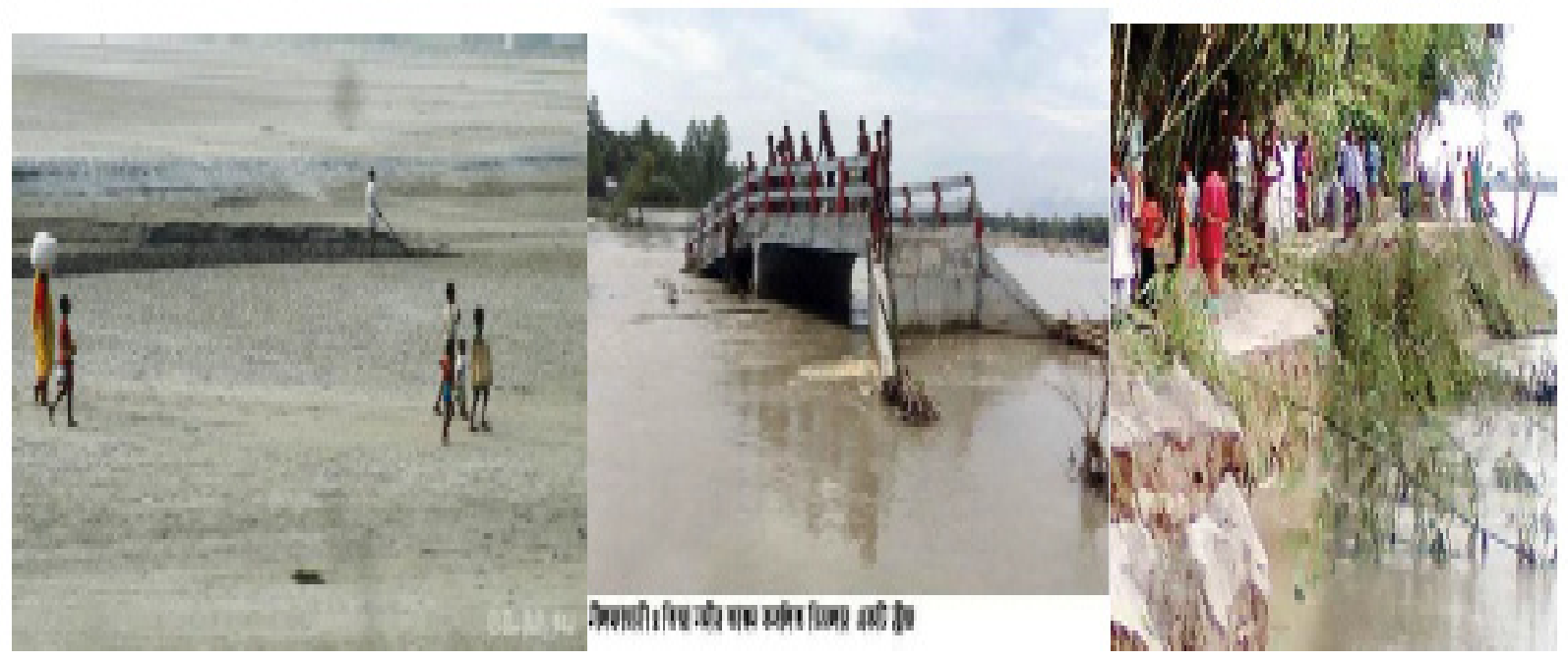

Fig. 26. Left inset: Dry Teesta bed due to heavy inland siltation. http://www.thedailystar.net/multimedia/country/ photo/teesta-wild-monsson-desert-winter-200800\#124930); middle inset: A bridge at Dimla at risk from the Teesta'serosiondueto theflooded Teesta(http://www.amardeshonline.com/pages/details/2016/07/15/344368\#. V4qo5LgrKUk, 15 July 2016); right inset: Teesta bank erosion erodes away the village Taiab Khan in Vidyananda Union in Qurigram district.

The flood in 2015 caused a loss of more than 190 million dollar. Crops in about 82,000 ha went under water in 8 districts of Rangpur Division totaling a loss of over 98 million dollars. In Sirajganj District crops in 10,498 ha were inundated by the flood water causing a loss of over 38 million dollars.

Qurigram District where 55,000 ha crop land was flooded had a loss of more than 51 million dollars (Thikana, 2015).

The silted river bed cannot accommodate the onrush water released by India by opening the gates of dams and barrages. The resulting strong current following the law of fluid flow through constricted area erodes the river bank. These catastrophic problems waste away established resources. Figs. 25 through 27 illustrate a recent flood situation. The loss of crops increases imports instead of exports.

3.2. Teesta Water Sharing. The Teesta water piracy is shown in Table 4 below

\begin{tabular}{|l|l|l|}
\hline Year & $\begin{array}{l}\text { Highest Discharge } \\
\text { (cumecs) }\end{array}$ & $\begin{array}{l}\text { Lowest Discharge } \\
\text { (cumecs) }\end{array}$ \\
\hline 1980 & 84,900 & 4494 \\
\hline 1990 & 158,096 & 4732 \\
\hline 2000 & 174,702 & 529 \\
\hline 2005 & 3,892 & 8 \\
\hline 2014 & ----- & $\begin{array}{l}42.45 \text { (January) } \\
11.57 \text { (march) }\end{array}$ \\
\hline
\end{tabular}

(http://archive.thedailystar.net/2006/11/03/d611031803114.htm) Source: Hydrology department, Rangpur 

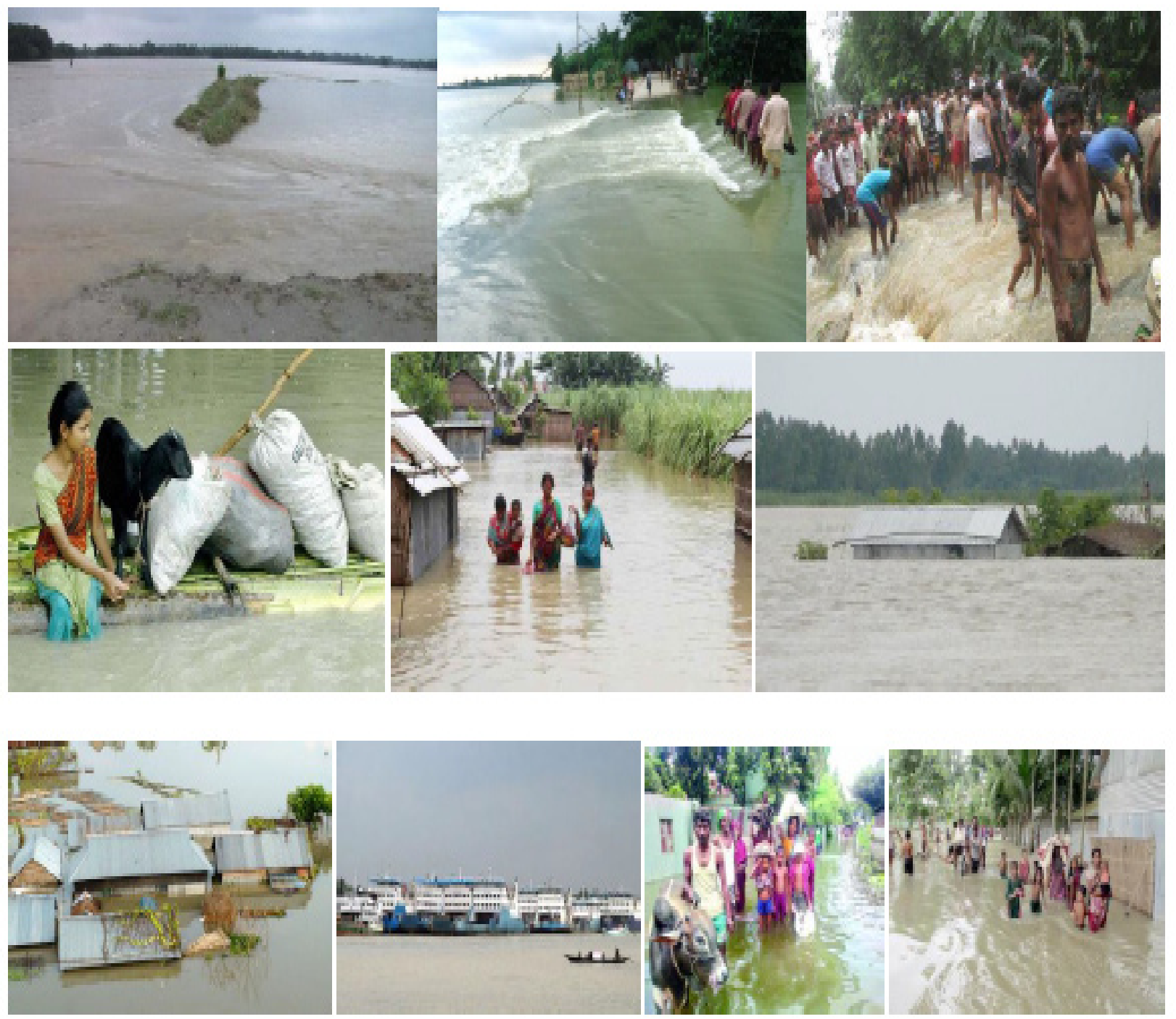

Fig 27. Some of the flood scenes due to opening of the gates of the Teesta Barrage at Gajaldoba and Farakka Barrage in West Bengal, India. Pictures speaks of the situations. 18a. India opens the 54 gates of the Gajaldoba Barrage at her will and without notifying Bangladesh to let the outlet Bangladesh flood. 18c. People are repairing the broken dyke. 18d. Flood situation deteriorates, more than a million peope are water-arrested.18e. Fear of heavy flooding in August, July 30. 18f. Fear of flood in the middle and southern part of Bangladesh as the flood water recedes in the Bay of Bangal to the south; 14 people died in the northern part, July 30.18g. Train communication affected due to rail lines submergence. 18h. Ferry communication adversely affected due to the strong current at Shimulia-Keorakandi as Farakka Barrage gates have been opened. 18i. Nobody looks at us (Courtesy of Amar Desh, July 30 and 31. 18j. People are trying to take shelter on high roads. http://www.amardeshonline.com/pages/ details/2016/07/30/346453\#.V53ppbgrKUk

Against the backdrop of all these effects, GDP can neither rise nor remain steady. 

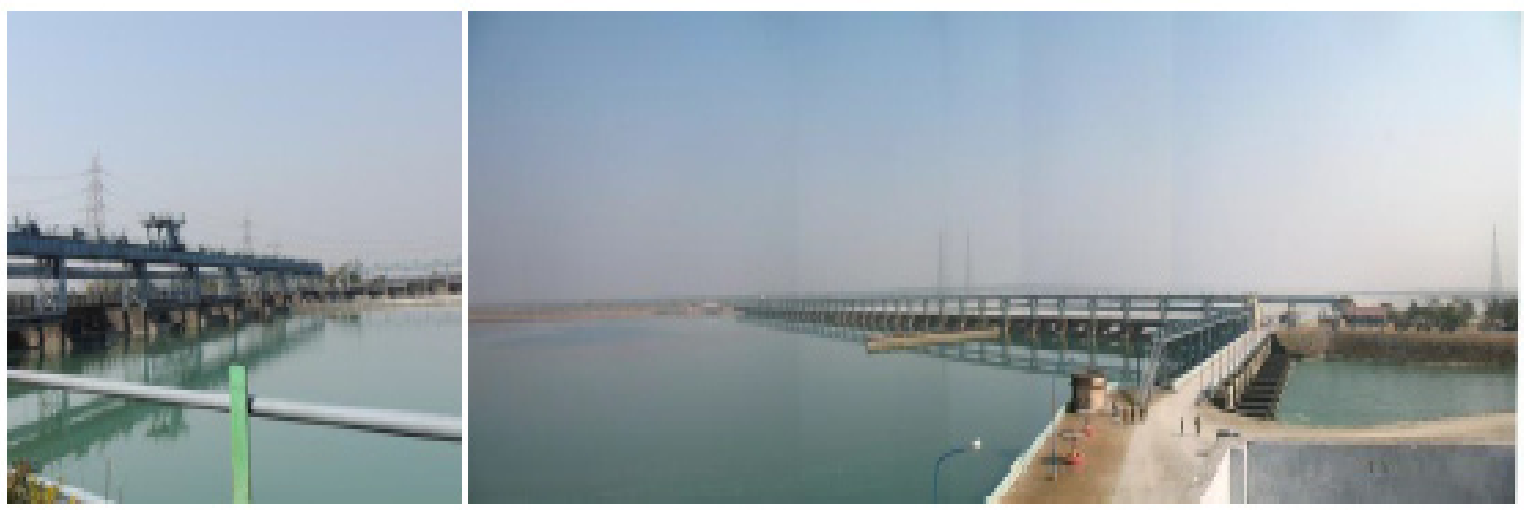

Fig 28. Left inset: The Mahananda Barrage (Paithanker, 2013); Right inset: Teesta Barrage (http://india-wris. nrsc.gov.in/wrpinfo/index.php?title=Teesta_Barrage,_St.I,_St.I_Ph.I_JI02921)

Indian water piracy from the Teesta River has lost the balance in the sectors of employment, agriculture, industries, and in nature. The Mahananda Barrage controls 15 rivers in northern Bangladesh. These are the Mahananda (Bangladesh part), the Korotoa, the Teesta, the Valuka, the Ranchandi, the Talma, the Ghoramara, the Buriteesta, the Versa, the Chilak, the Balam, the Pisla, the Dahuk, the Chawai, and the Qurum some of which are shown in Fig. 5B. The Teesta woes for the farmers are illustrated in Fig. 29. Dry Teesta canals in Bangladesh and the brimful canal with pirated water in India are pictured in Fig. 30.

Apart from irrigating about 0.922 ha lands in six districts of West Bengal, the Teesta project Fig. 27) supports 67.50-MW generation using the three water falls on the Mahananda main canal. Also, navigation and flood control is supported by the project.
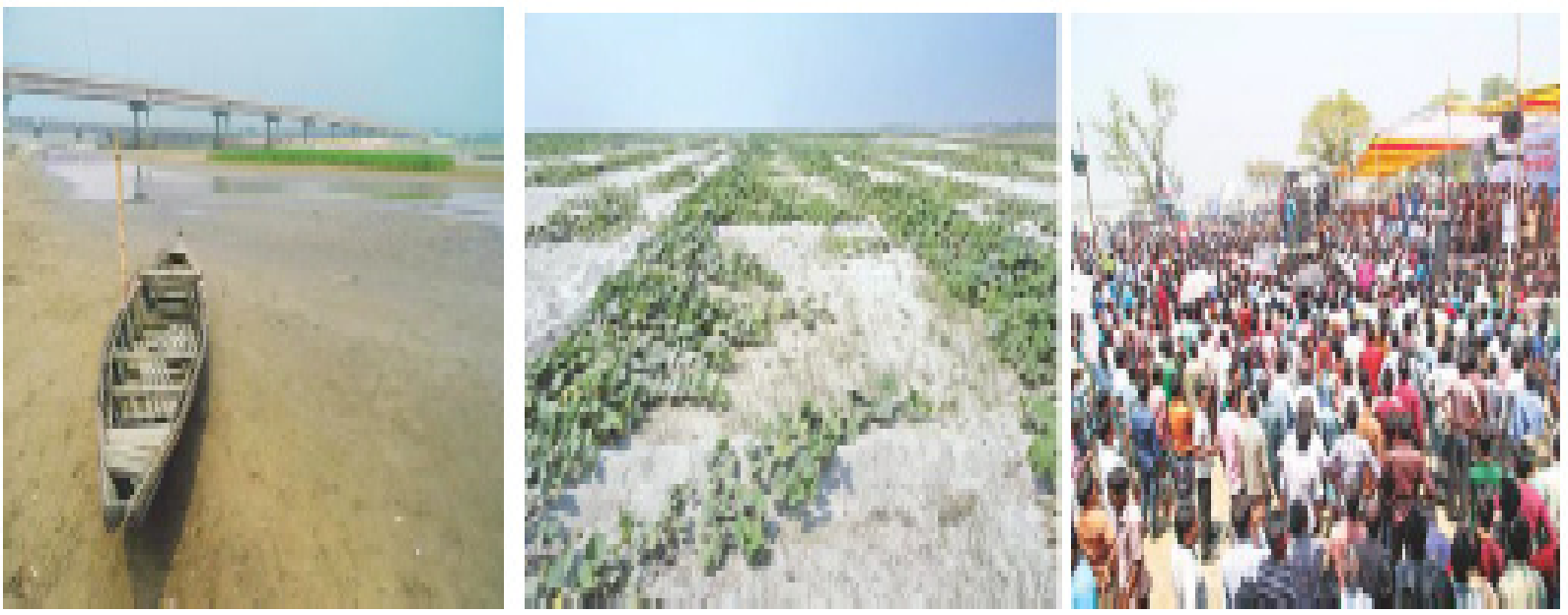

Fig 29. Left inset: Teesta woes for farmers. (http://www.thedailystar.net/print_post/teesta-woes-for-farmers20048) Pinaky Roy, 14 April 2014; middle inset: Silted and dry bed of Teesta (http://www.thedailystar.net/dueshare-must-for-good-indo-bangla-relation-21336 Pankaj Karmakar, 24 April 2014); right inset: People's rally against the Indian Teesta water piracy (Courtesy of Pankaj Karmakar, Daily Star, April 28, 2014. Available from http://www.thedailystar.net/due-share-must-for-good-indo-bangla-relation-21336 

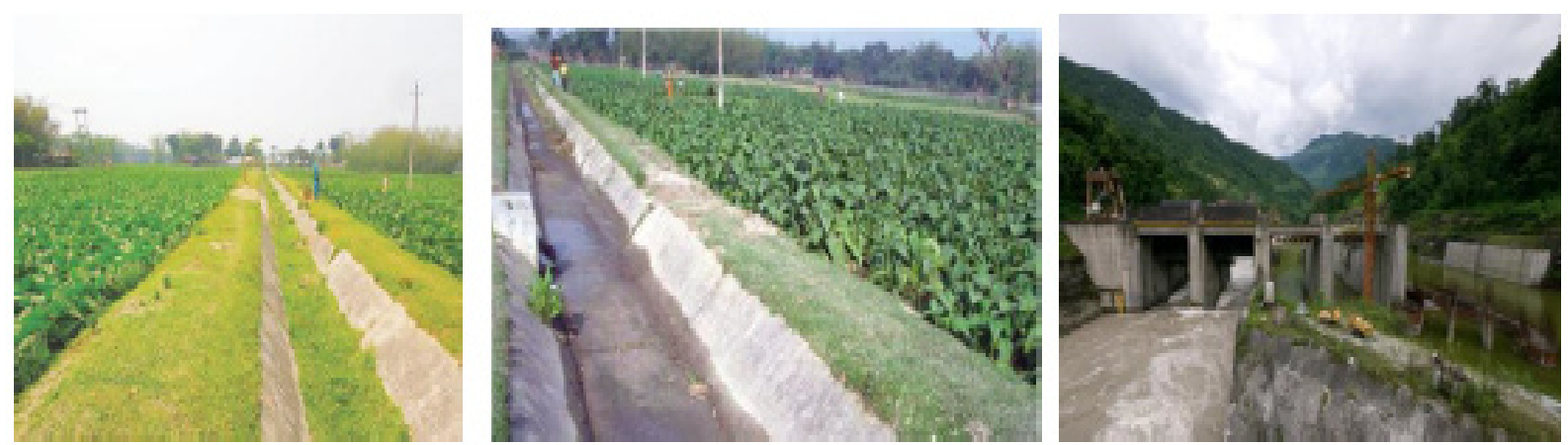

Fig 30. Right and middle insets: Dry Teesta canal. Farmer's cultivating tobacco leaving behind rice cultivation which takes more water than tobacco (Photo Daily Star, Asaduzzaman, Nilphamari, May 04, 2014); left inset:Teesta water in Indian canals (courtesy of Gogles)

In course of time, India will built a dam on the Barrack River, the headstream of the Meghna River to affect the economy of the Meghna basin

\subsection{India's Wet Season Water Piracy}

What India is planning now is to pirate the wet season Ganges water. In the upper reaches of the Ganges, there are the Upper Ganges Canals shown in Fig. 31 (total length $6582.22 \mathrm{~km}$ ), the Madhya Ganges Canals (will use the monsoon season

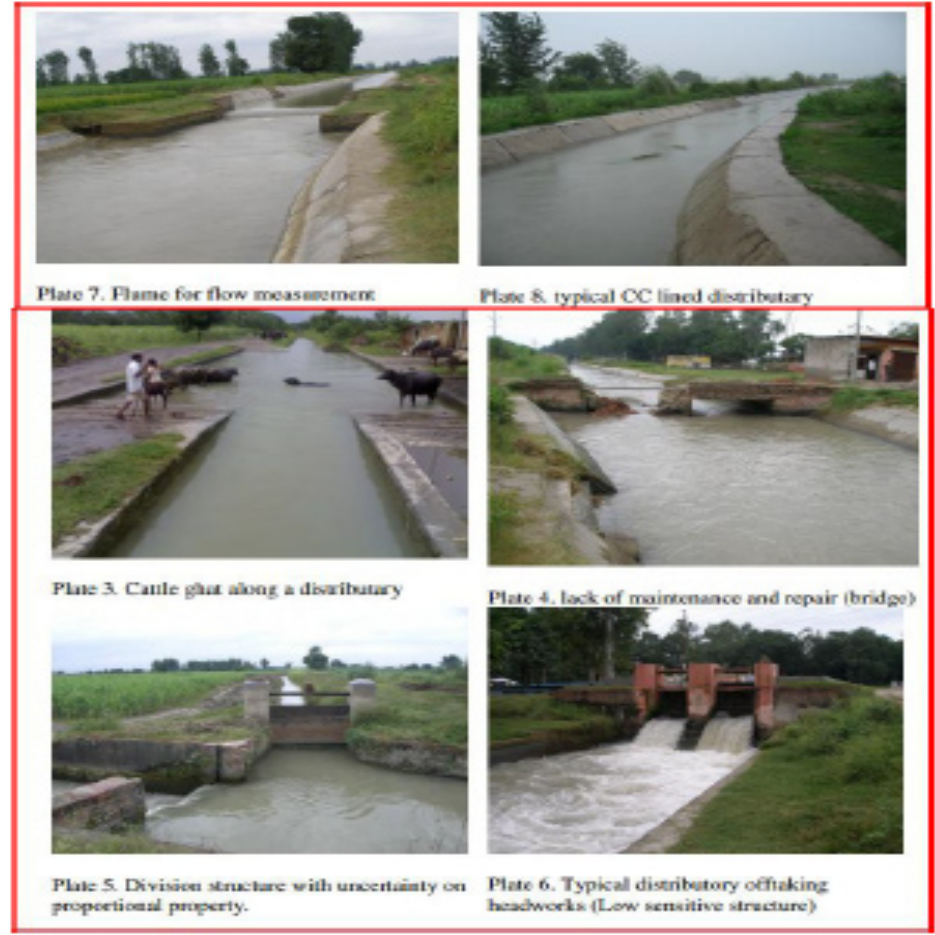

Fig. 31. Modernization of the Upper Ganges Canal (reproduced with permission http://www.fao.org/nr/water/ docs/masscote/applications/masscotemeerutreport.pdf) 
excess water of the Ganges for cultivating 64,000 ha paddy in dry pockets within the Upper Ganges Canal area. Also, it will develop paddy cultivation in 114,000 ha in the command area under the Upper Ganges Canal, and the Eastern Ganges Canals (a CCA of 2333,000 ha and an irrigation potential of 105,000 nha. is meant to use the monsoon season excess water from the Ganges for irrigation Bijnor and Moradabad districts of Uttar Pradesh. The canal network's, the total length is $203.09 \mathrm{~km}$. The Lower Ganga Canal consists of a 1,158-m long weir across Ganga at Narora to raise the winter Ganges discharge by $3.05 \mathrm{~m}$ to be fed into the canal that emerges from the right bank of the river. It irrigates 0.5 million ha in the districts of Mainpuri, Etah, Farrukhabad, Etawah, Kanpur, Fatchpur, and Allahabad in Uttar Pradesh.

The Main Canal and branches in the Lower Ganges Canal measure about 1,060 km, and distributaries 5,015 $\mathrm{km}$. The combined service of the Upper and the Lowe Ganges Canals form the world's largest irrigation system - no less than 12,240 km long to irrigate an area of 1 million ha. Hillary, a traveller on the Ganges, reports that during the dry season almost all the water is taken by India at Hardwar (1979).

\section{4. Intellectual Degeneration}

Some of economists in Bangladesh is just supporters of the government. Some others follow unholistic approach in their research. The first group of economists praises the government. They do not speak the truth. They are run by personal interersts. The second group of economists, too, portrays a wrong picture of the country. They do research on superficial things to increase their publications for their vitae (Ahmed, et al, 2008; Ahmed and Luog-Van 2009; Ahmed, 2010; Ahmed et al, 2010), Ahmed et al, 2011) by giving a wrong picture of the country at home and abroad. In the absence of surface water, farmers use groundwater for rice cultivation along which they raise fish (Fig. 10). Economists call it a green revolution and produce articles after articles on removing poverty through simultaneous double cropping - rice and fish. Almost $50 \%$ of the water raised evaoporates and another $50 \%$ infiltrates into the ground. It takes hundreds to thousands of years to build groundwater. Through the "green revolution", Bangladesh is losing the last resort, the groundwater. Water is so scarce a commodity that cannot be bought, and Bangladeshi economists call the farmers' exhausting of this commodity a green revolution. This intellectual degeneration is suicidal for the country.

Historically speaking, the GDP idea was introduced when no countries of the world were pirating or had the idea of piracy of the renewable natural resource of another country - not even the colonial powers.

\section{Some Other Upstream Water Piracy-Affected Basins}

There is the dispute between India and Pakistan in the Indus River basin on the Jhelum River that Pakistan has exclusive rights on. India is diverting water from its tributary the Kishenganga River. Without understanding the widespread effect, the judges in the International court passed verdict in favor of India.

The Ratle Hydroelectric Plant (133-m tall gravity dam and two adjacent power stations of installed capacity 850 MW) is currently under construction on the Chenab River that Pakistan holds exclusive right over according to the Indus Water Treaty. India's Modi Government will not allow water to flow through Pakistan (http:// www.dawn.com/news/1298575/water-belonging-to-india-cannot-go-to-pakistan-says-modi), a stance that breaks the Indus Water Treaty signed by the two countries in 1960. India will accelerate its building of new 
hydro-power plants along three rivers that flow into Pakistan (http://www.dawn.com/news/1286433/indiato-speed-up-hydropower-building-on-rivers-flowing-into-pakistan)

Pakistan's friend China may be persuaded to stop flow of the Brahmaputra River water through India in the event of India's depriving Pakistan of water. China's construction of mega size multiple dams on the Mekong River will deprive about 60 million downstream people of the quantity and quality of water they need in Cambodia, Laos, Thailand, and Vietnam. Among the number of already constructed dams of more than 10-MW capacity, China has 5, Laos 9, Cambodia 2, Vietnam 8, and Thailand 7.

Turkey plans to develop 22 dams and 19 hydroelectric projects utilizing the Tigris-Euphrates discharges. Also, Turkey plans to divert water using canals to irrigate 1.7 million ha of land. Both Zimbabwe and Botswana's proposal for upstream piracy of the Zambeszi's water will adversely affect the downstream countries' economy. Slovakia's unilaterally implemented plan on the Danube basin affected Hungary's economic growth.

Ethiopia's plan to set up Africa's largest power plant in the Nile basin will affect Egypt and Sudan seriously. Spain nourishes the greed of pirating 1 billion cubic meter of watert from the Douro River water without consultation with Portuguese. The piracy water from the Jordan River by either Jordan or Israel will affect the other. In the past, the United States pirated water from the Rio Grande and the Coloradi Rvers affecting Mexican economy.

\section{GDP THE MEASURE OF ECONOMIC GROWTH}

GDP is the market value of all finished goods and services within a country. Out of the three ways of determining GDP for victim countries in the presence of water piracy, the expenditure approach is the direct one because the labor cost and the irrechargable groundwater cost as well as other costs in the production of crops can be put together. However, the expenditure approach works on the principle that the total product must be equal to people's total expenditures. Upstream water pirates made GDP an invalid indicator of economic health for the downstream victims as is seen from the following GDP formula:

$\mathrm{GDP}=\mathrm{C}+\mathrm{I}+\mathrm{G}+(\mathrm{X}-\mathrm{M})$

where, $\mathrm{C}=$ consumers' consumptions,

$\mathrm{I}=$ gross investment,

$\mathrm{G}=$ government spending,

$\mathrm{X}=$ exports, and

$\mathrm{M}=$ imports

(http://en.wikipedia.org/wiki/Gross_domestic_product No mentions of the loss or the deterioration of the country's permanent renewable resources are made in the formula because GDP was introduced at a time when no nation was pirating the renewable natural resource of another nation.

If the resource for production is looted away, the country has to import that resource which is costly for water and will not be available for purchasing.

Volume 3

Page 27 


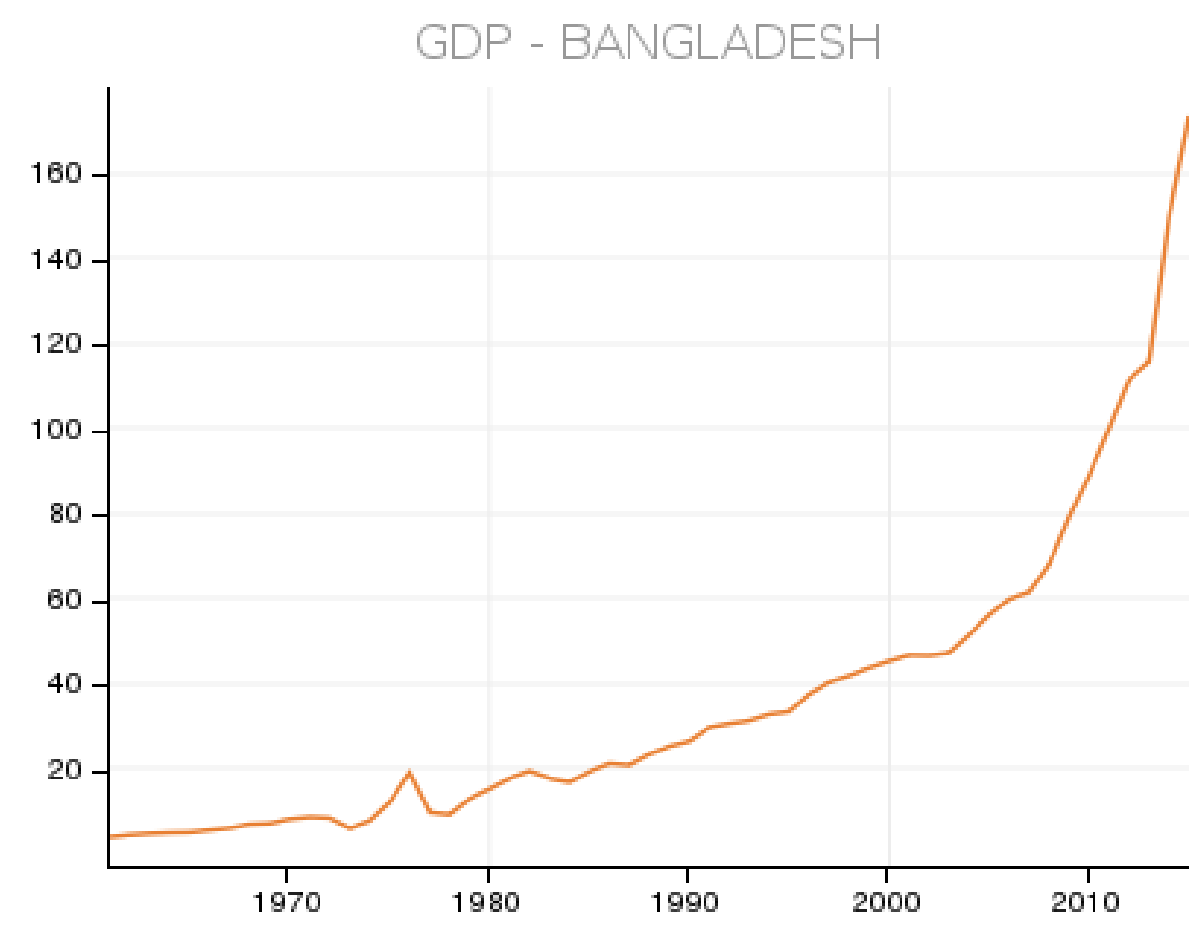

Fig. 32. Increasing GDP of Bangladesh at glance in dependent of the depletion of the renewable natural resources (https://www.quandl.com/collections/bangladesh/bangladesh-economy-data)

It is surprising that inspite of her water resource piracy, the GDP of Bangladesh is ever increasing.

\section{Discussions AND CONCLUSIONS}

Water is elixir of life. Its internationality cannot the denied. Its continued shortage can create an environmental havo, viz.- ecocide occurs. The very basic element of production is lost. The four positive terms in GDP, viz. consumption, investment, government spending and export are all affected in the water-deprived downstream countries. Under these circumstances, naturally resourcefull countries' GDP cannot be compared with the natural resource-depleting countries due to the piracy at the upstream. An affected country may show increased production in another sector in this age of technological development, but it cannot make up for what the pyrated resource could do. Following the rise of environmental problems, countries may increase services to be counted in the GDP determination, but with the unavailability of the production water, the radical environmental changes produced are irremovable. Practically speaking, the country will run in the red and the actual GDP will drop below zero. Human sufferings must be considered in the wake of the upstream water piracy to stop this activity. The world has enough resources to meet our needs but not to meet anybody's limitless greed.

\section{ACKNOWLEDGEMENTS.}

The author expresses sincere thankfullness to all those whose facts and figures have been incorporated in this article to arouse awareness to the economists community. 


\section{REFERENCES}

Adel, M. M., 1999a. The impact of climatic extremes and water shortage upon human health, World Resource Review, vol. 11 no. 4, pp. 576-601

Adel, M. M. 1999b. Integrated investigation of the arsenic episode in Bangladesh, Indian Journal of Environmental Protection, vol. 19 no. 9, pp. 652-660

Adel, M. M., 2000. Microlevel climate change in the Ganges basin, Journal of the Arkansas Academy of Sciences, vol. 53, pp. 83-91

Adel, M. M., 2000a. Arsenic contamination in the groundwater of Biosphere III: causes and remediation, pp.71-80. In H. Inyang and V. Ogunro, eds., Proceedings of the Fourth International Symposium on Environmental Geotechnology and Global Sustainable Development, Boston, MA.

Adel MM (2001). Effects on Water Resources from Upstream Water Diversion in the Ganges Basin, Journal of Environmental Quality. 30:336-368.

Adel, M. M. 2002. Man-made climatic changes in the Ganges basin, International Journal of Climatology, vol. 22, pp. 993-1016

Adel, M. M. 2003. Biosphere III: the site of the unprecedented ecocide in the Ganges basin, pp. 59-79. In J. Ahmed, ed., National Documentation on the Problems of Arsenic and Farakka, published by the International Farakka Committee, Inc. New York, NY

Adel, M. M. 2004a. Impacts from transboundary water rights violations in South Asia, pp. 205-214 in R. Murray, M. K. Jacobson, and S. Anderson, eds., Proceedings of the 2004 Water Management Conference: Water Rights and Related Water Supply Issues, Salt Lake City, Utah

Adel, M. M. 2004b. Upstream water diversion constructions on transboundary river, pp. 547556. in R. Murray, M. K. Jacobson, and S. Anderson, eds., Proceedings of the 2004 Water Management Conference: Water Rights and Related Water Supply Issues, Salt Lake City, Utah

Adel, M. M. 2005. Background state leading to arsenic accumulation in the Bengal basin groundwater, Journal of Water and Health, vol. 3 no. 4, pp. 435-452

Adel, M. M. 2008a. Natural river flow obstruction risks groundwater arsenic contamination, UNESCO-Sponsored International Conference on Water Scarcity, Global Changes and Groundwater Management Responses, University of California at Irvine, California, 1-5 December, 2008.

http://www.groundwater.conference.uci.edu/files/chapter1/2008_conf_AR

Adel, M. M. 2008b. Ordeals to have due share of trans-boundary river water, UNESCO- Sponsored International Conference on Water Scarcity, Global Changes and Groundwater Management Responses, University of California at Irvine, California, 1-5 December, 2008 http://www.groundwater.conference.uci.edu/files/ chapter2/2008_conf_AR

Adel, M. M., 2008c. International migration of Gangetic fishermen in South Asia, International Conference on Environment, Forced Migration \& Social Vulnerability, Bonn, Germany, 9-11 October, 2008. http://www. efmsv2008.org/files/International+Migration+of+Ganges +fishermen+In+South+Asia+?menu=12 
Adel, M. M., 2012a. Downstream ecocide from upstream water piracy. American Journal of Environmental Sciences, 8: 528-548.DOI: 10.3844/ajessp.2012.528.548

Adel, M. M., 2012b. Ecosystems sustainability challenges from international river water plunderage, pp. 58-66. in S. Rab ed. Proceedings of the 3rd ABC Convention, Astoria World Manor, Astoria, Queens, NY, June 23-24, 2012

Adel, M. M. 2013a. Jaladasyupana (in Bengali) meaning water piracy. Published by Dibbo Prakash, Dhaka, Bangladesh

Adel, M. M., 2013b. Farakka Barrage, the greatest ever riparian bluff for upstream water piracy, Academia Journal of Environmental Sciences 1(3):036-052, March 2013

Adel, M. M., 2013c.Upstream water piracy contaminates downstream water, Environmental Justice vol.6 No. 3, pp. 103-114, 2013. Mary Ann Liebert, Inc. DOI: 10.1089/env.2013.0008

Adel, M. M., 2013d. Environmental pollution through indiscriminate arsenic waste disposal, Journal of Ecological Science research, vol. 1(1), pp.1-26, September 2013; Online:http://www.projournals.org/JESR

Adel, M. M., 2013e. Upstream water piracy impact upon the aquatic world and human dimension-some water piracy curses, Environment and Ecology Research Journal, vol. 1(4), pp. 161 -195 D0I:10.13189/ eer.2013.010401

Adel, M. M., 2013f, Upstream water piracy the strongest weapon to corner a downstream nation, Environment and Ecology Research Journal, I(3):85-123, 2013 D0I: 1013189/eer.2013.010301

Adel, M. M., 2013g,Cunning strategy for upstream water piracy and its remedial measures, Environmental Justice, vol. 6, no. 4, pp. 145-162, 2013 DOI: 10.1089/env.2013.0005

Adel, M. M. 2015a. Farakka Barrage Vol 1: The Symbol of Bluffing, Blackmailing, Bullying, and Cornering Downstream for Upstream Water Piracy, published by German Academic Publishing Company Lap Lambert

Adel, M. M. 2015b. Farakka Barrage Vol 2: The Symbol of Bluffing, Blackmailing, Bullying, and Cornering Downstream for Upstream Water Piracy, published by German Academic Publishing Company Lap Lambert

Adel, M. M. 2015c. The Dam-Deluged Gasping Ganges Vol. 1, published by German Academic Publishing Company Lap Lambert

Adel, M. M. 2015d. The Dam-Deluged Gasping Ganges Vol. 2, published by German Academic Publishing Company Lap Lambert

Adel, M. M. 2015e The Dam-Deluged Gasping Ganges Vol.3, published by German Academic Publishing Company Lap Lambert

Adel, M. M., 2016 Treeteo Jobjagat (in Bengali) meaning Bio-World III. The author presents a case study of the integrated effects of drying rivers at the downstream by the upstream water piracy in the Ganges basin. Publisher Dibbo Prakash, Dhaka, Bangladesh (in press)

Adel, M. M. and M. Husain, 2008. Sono filter waste disposals contradict safe environmental regulations, UNESCOSponsored International Conference on Water Scarcity, Global Changes and Groundwater Management Responses, University of California at Irvine, California, 1- 5 December, 2008. 
Adel, M. M, and M Husain, 2014. Environmental pollution through indiscriminate arsenic waste disposal, Journal of Ecological Science research, vol. 1(1), pp.1-26, September 2013; Online:http://www.projournals.org/ JESR http://www.groundwater.conference.uci.edu/files/chapter1/2008_conf_AR

Adel MM, Hossain MR, and Hossain SF (2014). Climatic Severity Victims of Upstream Water

Piracy Strongly Evidencing Inland Water Depletion-Caused Global Warming Vis-à-vis Cooling, American Journal of Environmental Science. 10(2):171-198. Dio:10.3844/ajesp.2014.171.198 Published Online 10(2) 2014 (http://www.thesciencepub.com/ajesp.toc)

Adel, M. M., M. R. Hossain, and S. F. Hossain, 2014. Climatic severity victims of upstream water piracy strongly evidencing inland water depletion-caused global warming vis-a - vis cooling, American Journal of Environmental Science 10 (2): 171-198, 2014 ISSN:

1553-345X (C2014 Science Publication; doi:10.3844/ajessp.2014.171.198 Published Online 10 (2) 2014 (http://www.thescipub.com/ajes.toc)

Ahmed N, Brown J H, Muir JF(2008), Freshwater prawn farming in gher systems in southwest Bangladesh, Aquacul. Econ. Mgmt. 12 (3), 207-223.

Ahmed N, Luong-Van J (2009), Can rice-fish farming provides food security in Bangladesh? Aquacul. Asia Mag. XIV (1), 18-23.

Ahmed N, Garnett ST (2010), Sustainability of freshwater prawn farming in rice fields in southwest Bangladesh, J. Sus. Ag. 34 (6), 659-679.

Ahmed N, Allison EH, Muir JF (2010), Rice fields to prawn farms: a blue revolution in southwest Bangladesh? Aquacult. Int. 18:855-574.

Ahmed N, Zander KK, Garnett ST (2011), Socioeconomic aspects of rice-fish farming in Bangladesh: opportunities, challenges and production efficiency, Austral. J. Ag. Res. Econ. 55, 199-219.

Amar Des, Desk Rerport, Baro nadigulote pani bredhdhi, Barsan abyahata thakle banyar ashanka 18 July 2016. Available from http://www.amardeshonline.com/pages/details/2016/07/18/344743\#.V4y_7rgrKUk

BADC (Bangladesh Agricultural Development Corporation), (2002). Survey report on irrigation

equipment and irrigated area in Boro/2001 season. Bangladesh Agricultural Development Corporation, Dhaka

Dey, N. C., S. K. Bala, A. K. M. S. Islam, M. A. Rashid, and M. Hossain. 2013. Northwest Bangladesh, BRAC, Available from http://www.nfpcsp.org/agridrupal/sites/default/files/ToR-2.pdf

M. Husain, M. M. Adel, et al., 2010.Freedom Water Filtration System-A solution to the arsenic and pathogen contaminated water crisis in Bangladesh and other underdeveloped nations, 4th International Conference on Water Resources \& Arid Environments (ICWRAE-4), 184-213, http://www.icwrae- sipw.org/images/ stories/2010/Water Resources/21/index.html InternationalJournal of Water Resources \& Arid Environments (2010)

Krantz, M. 1999. COASTAL EROSION ON THE ISLAND OF BHOLA, BANGLADESH Magnus Krantz ISSN 14003821 B178 Projketarabete Göteborg 1999 Postadress Besöksadress Telefo Telfax Earth Sciences Centre Geovetarcentrum Geovetarcentrum 031-773 1951 031-773 1986 Göteborg University S-405 30 Göteborg Guldhedsgatan 5A S-405 30 G 
Miah, M. A. 1989. Uttar-Pashchim Bangladesher Charambhabapanna Abhawa meaning the extreme weather in north-west Bengal basin (in Bengali).

Miah, M. A., 1996a. The water crisis in Bangladesh: a challenge to integrated water management in urban areas, Environmental Research Forum, vol. 3-4, pp. 69-86,

Miah, M. A., 1996b. Farakka Barrage: an unprecedented environmental disaster in the Ganges basin, pp. 18-31, in T. S. Rehman, ed., Perspectives of the Thirty-Year Water-Sharing Treaty, Bangla Bazar Publisher, Dhaka, Bangladesh

Pfly, The Brahmaputra, Gangrs, and Meghna Basins. 30 April 2011. Available from http://commons.wikimedia. org/wiki/File:Ganges-Brahmaputra-Meghna_basins.jpg

Wolf AT, Natharius JA, Danielson JJ, Ward BS and Pender JK, (1999). International River Basins of the World, International Journal of Water Resources Development, 15:4, 387-427, DOI:10.1080/07900629948682

Citation: Miah M Adel, "Upstream Natural Resource Piracy-Caused Universality-Lost Economic Health Index GDP". American Research Journal of Biosciences; Volume 3, 2017; pp:1-32

Copyright (C) 2017 Miah M Adel, This is an open access article distributed under the Creative Commons Attribution License, which permits unrestricted use, distribution, and reproduction in any medium, provided the original work is properly cited. 